\title{
Catalytic Steam Reforming of Biogas - Effects of Feed Composition and Operating Conditions
}

\author{
Shabbir Ahmed*, Sheldon H.D. Lee, Magali S. Ferrandon \\ Chemical Sciences and Engineering Division, Argonne National Laboratory, 9700 S. Cass \\ Avenue, Argonne, IL 60439, USA
}

Corresponding Author. Email: ahmeds@anl.gov, Tel: 1-630-252-4553, Fax: 1-630-972-4553 


\begin{abstract}
A study was conducted on the steam reforming of biogas mixtures over a $4 \mathrm{wt} . \% \mathrm{Rh} / \mathrm{La}-$ $\mathrm{Al}_{2} \mathrm{O}_{3}$ catalyst, where the effects of temperature $\left(590-685^{\circ} \mathrm{C}\right)$, steam $(\mathrm{S} / \mathrm{C}$ molar ratio $=$ 1.28-3.86), $\mathrm{CO}_{2} / \mathrm{CH}_{4}$ molar ratio (0.55-1.51), and the gas hourly space velocity $(9,810-$ $27,000 \mathrm{hr}^{-1}$ ) on the conversions and product yields were evaluated. Within these ranges, temperature and steam had the most pronounced effect on methane and carbon dioxide conversions. The highest methane conversion observed was 99\%. Low temperatures and high $\mathrm{S} / \mathrm{C}$ resulted in a net $\mathrm{CO}_{2}$ production. The water gas shift reaction appeared to have a stronger effect on the $\mathrm{CO}_{2}$ conversion than the $\mathrm{CO}_{2}$ reforming reaction. Experimental methane conversions were lower than the equilibrium predicted values. Lower temperature operations yielded a lower carbon balance suggesting the tendency to form carbonaceous species other than $\mathrm{CO}, \mathrm{CO}_{2}$, and $\mathrm{CH}_{4}$. The presence of $\mathrm{CO}_{2}$ in the biogas contributed to the $\mathrm{CO}$ yield (beyond that from $\mathrm{CH}_{4}$ steam reforming) only above certain $\mathrm{CO}_{2} / \mathrm{CH}_{4}$ ratios.
\end{abstract}

Keywords: Biogas, hydrogen, reforming, rhodium catalyst, $\mathrm{S} / \mathrm{C}$ molar ratio, $\mathrm{CO}_{2} / \mathrm{CH}_{4}$ molar ratio, $0 / C$ ratio, gas hourly space velocity, catalyst durability 


\section{Introduction}

Biogas is commonly referred to a gas produced by the biological breakdown of organic matter in the absence of oxygen, such as the anaerobic digestion or the fermentation of biodegradable materials of algal biomass, manure, municipal waste in landfills, sewage sludge in waste water treatment plants, rubbish dumps, septic tanks, green waste and energy crops, etc. This type of biogas comprises primarily methane and carbon dioxide [1]. Other components present include moisture, nitrogen, volatile organic compounds, and sulfur species - primarily hydrogen sulfide. The actual composition of biogas varies depending on the anaerobic digestion process and the feedstock [2].

Biogas has been accepted to be a versatile renewable energy source and in receiving increased interest [3] because it can be used to replace fossil fuels for power and heat productions, and thus play an important role in minimizing global warming and climate change impacts. For biogas utilization, one widely studied subject is the biogas upgrading [4-6] through carbon-dioxide removal by physical separation technologies. This generates a methane-rich biogas (biomethane) as a natural gas substitute for various applications, including as a feedstock for producing chemicals and materials and its direct connection to pipe-line for network distribution. Biogas steam and oxidative reforming [7-10] have also received considerable research studies for either producing synthesis gas (a mixture of $\mathrm{H}_{2}$ and $\mathrm{CO}$ ) suitable for many industrial synthesis processes for fuels, such as gasoline, gasoil, kerosene, aldehydes, and alcohols [11-12] or producing hydrogen for fuel cell applications.

The methane in the biogas can be reformed by the steam methane reforming reaction and by the $\mathrm{CO}_{2}$-reforming reaction.

Steam Methane Reforming (SMR): $\quad \mathrm{CH}_{4}+\mathrm{H}_{2} \mathrm{O}=3 \mathrm{H}_{2}+\mathrm{CO} \quad \Delta \mathrm{H}_{298}=49 \mathrm{kcal} / \mathrm{mol} \quad$ (1)

$$
\mathrm{CO}_{2} \text {-Reforming (CR): } \quad \mathrm{CH}_{4}+\mathrm{CO}_{2}=2 \mathrm{H}_{2}+2 \mathrm{CO} \Delta \mathrm{H}_{298}=59 \mathrm{kcal} / \mathrm{mol}
$$

Both of these reactions are highly endothermic and are favored by low pressures and high temperatures. The thermodynamics, catalyst selection and activity, reaction mechanisms, and kinetics of this $\mathrm{CO}_{2}$-reforming reaction were reviewed in the literature [13].

In addition to these major reforming reactions, other potential side reactions include:

$$
\begin{array}{llll}
\text { Water Gas Shift (WGS) Reaction: } & \mathrm{CO}+\mathrm{H}_{2} \mathrm{O}=\mathrm{H}_{2}+\mathrm{CO}_{2} & \Delta \mathrm{H}_{298}=-10 \mathrm{kcal} / \mathrm{mol} & \text { (3) } \\
\text { Methane Decomposition Reaction: } & \mathrm{CH}_{4}=2 \mathrm{H}_{2}+\mathrm{C} & \Delta \mathrm{H}_{298}=18 \mathrm{kcal} / \mathrm{mol} & \text { (4) } \\
\text { Boudouard Reaction: } & 2 \mathrm{CO}=\mathrm{CO}_{2}+\mathrm{C} & \Delta \mathrm{H}_{298}=-41 \mathrm{kcal} / \mathrm{mol} & \text { (5) }
\end{array}
$$


At the reformer temperatures, organic sulfur in the biogas can also react with hydrogen and carbon oxides to form $\mathrm{H}_{2} \mathrm{~S}$ and COS.

The $\mathrm{CO}_{2}$-reforming of methane (reaction 2) offers some advantages over the steam reforming of methane (reaction 1 ). It produces a synthesis gas with a lower $\mathrm{H}_{2} / \mathrm{CO}$ ratio $(\sim 1)$ that is a preferable feed gas and has higher energy efficiency for producing liquid fuels via the Fischer-Tropsch reaction [14]. The higher endothermicity of the reaction is attractive for conversion of solar or nuclear energy to chemical energy for storage in the form of $\mathrm{CO}$ and $\mathrm{H}_{2}$. Catalyst deactivation during $\mathrm{CO}_{2}$-reforming reaction has been a major obstacle in commercial implementation of this reaction. Coke formation is the primary reason for the catalyst deactivation [15-17] and it can be significantly inhibited by adding a small amount of steam [18]. Thus steam reforming of biogas to utilize the combined steam reforming and $\mathrm{CO}_{2}$-reforming of methane can be a viable process for producing synthesis gas from biogas. Effendi, et al. has studied the steam reforming of a clean model biogas in fluidized- and fixed-bed reactors [19-20].

Recent research has also centered on the development of catalysts for biogas reforming [21-23]. In our in-house studies, a Rh supported on La-stabilized $\mathrm{Al}_{2} \mathrm{O}_{3}$ catalyst has been shown to have significantly higher activity and hydrogen selectivity for reforming reactions than other noble-metal catalysts [24]. This catalyst also showed good longterm stability than $\mathrm{Rh}$ onY- $\mathrm{ZrO}_{2}, \mathrm{Gd}-\mathrm{CeO}_{2}, \gamma-\mathrm{Al}_{2} \mathrm{O}_{3}$ and $\mathrm{CaAl}_{12} \mathrm{O}_{19}$, and was selected in our earlier work for the studies of autothermal reforming of natural gas [25] and steam reforming of ethanol [26]. Because of its good catalytic performance characteristic, this catalyst was selected in this study for steam reforming of biogas to produce a hydrogenrich stream that can be used for upgrading biofuels.

\section{Experimental}

Catalyst: $\quad$ A Rh supported on La-stabilized $\mathrm{Al}_{2} \mathrm{O}_{3}$ catalyst was used in this study. Based on literature data and in-house experience [24], the La-stabilized alumina was selected as the support for Rh since (1) lanthanum as a basic oxide supports gasification of carbon in reforming reactions; (2) lanthanum forms a lanthanum aluminate $\left(\operatorname{LaAlO} \mathrm{O}_{\mathrm{x}}\right)$ at the surface which has been shown to prevent the migration of Rh into the support. $A$ $4 \mathrm{wt} . \% \mathrm{Rh} / \mathrm{La}-\mathrm{Al}_{2} \mathrm{O}_{3}$ was prepared in house using the incipient wetness technique by adding a sufficient amount of solution containing rhodium nitrate $\left(\mathrm{Rh}\left(\mathrm{NO}_{3}\right)_{3}-2 \mathrm{H}_{2} \mathrm{O}\right.$, Alfa

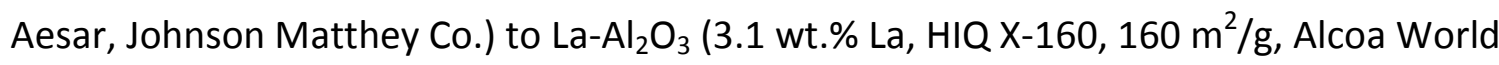
Alumina) to yield a $4 \mathrm{wt} . \%$ loading of $\mathrm{Rh}$. The $4 \mathrm{wt} . \% \mathrm{Rh} / \mathrm{La}-\mathrm{Al}_{2} \mathrm{O}_{3}$ was then dried overnight at $100^{\circ} \mathrm{C}$ and calcined by heating from room temperature to $700^{\circ} \mathrm{C}$ at $5^{\circ} \mathrm{C} / \mathrm{min}$ heating rate, followed by holding at the temperature for $1 \mathrm{hr}$. The catalysts were 
crushed and sieved to particle sizes between 150 and 250 microns before being loaded into the reactor for experimental testing. The BET surface area of the calcined catalyst was $122 \mathrm{~m}^{2} / \mathrm{g}$.

Biogas mixtures: A certified-grade cylinder mixture of methane and carbon dioxide was used as a biogas surrogate for experimental testing in this work. Table 1 shows four cylinder mixtures (Airgas USA, LLC) that were used for this study. As will be shown in the next section, the mixture was further mixed with controlled amounts of nitrogen (also served as a controlling inert for chemical analysis of the product gas) and steam to form a feed stream to the reactor.

Table 1. Chemical composition of the biogas mixtures studied

\begin{tabular}{|c|c|c|c|}
\hline \multirow{2}{*}{ Biogas Mixture } & \multicolumn{2}{|c|}{ Chemical Composition, \% } & \multirow{2}{*}{$\mathrm{CO}_{2} / \mathrm{CH}_{4}$ Feed Ratio } \\
\cline { 2 - 4 } & $\mathrm{CO}_{2}$ & $\mathrm{CH}_{4}$ & \\
\hline 1 & 60.22 & 39.78 & 1.51 \\
\hline 2 & 49.42 & 50.58 & 0.98 \\
\hline 3 & 39.54 & 60.46 & 0.65 \\
\hline 4 & 35.42 & 64.58 & 0.55 \\
\hline
\end{tabular}

Experimental apparatus: Figure 1 shows the schematic of the micro-reactor process system installed in this work for studying the steam reforming of biogas mixtures (Table 1). A controlled amount of $\mathrm{CH}_{4} / \mathrm{CO}_{2}$ mixture is pre-mixed with a controlled amount of nitrogen and then flow directly to the steam generator (controlled at $120^{\circ} \mathrm{C}$ ), inside which a heater rod is packed with copper chips to enhance the heat transfer and mixing of gaseous flows. The outlet mixture from the steam generator is fed through a heattraced gas process line (maintained at $\sim 150^{\circ} \mathrm{C}$ ) down-flow directly into the reactor tube (9.5-mm OD) where a 12.7- $\mathrm{mm}$ length of catalyst bed $(0.50 \mathrm{~g})$ is installed and supported by a layer of quartz-wool and an inner insert tube. The reactor tube is heated by a tubular furnace and the temperature of the catalyst bed is monitored with thermocouples placed at the inlet (top) and exit (below) the catalyst bed. The product gas exits at the bottom of the reactor tube and flows through a heat-traced gas process line to a condenser that is controlled at $15^{\circ} \mathrm{C}$ to condense out most of the moisture of the product gas. The product gas is further cooled to $2^{\circ} \mathrm{C}$ in a chiller before it flows through a flowmeter and into a gas chromatograph. The concentrations of $\mathrm{H}_{2}, \mathrm{CO}_{2}, \mathrm{~N}_{2}$, 
$\mathrm{CH}_{4}$ and $\mathrm{CO}$ in the product gas were determined by Hewlett Packard Model 5890 Series II gas chromatography installed with the Alltech washed molecular sieve 5A and Hayesep D columns and thermal conductivity detector.

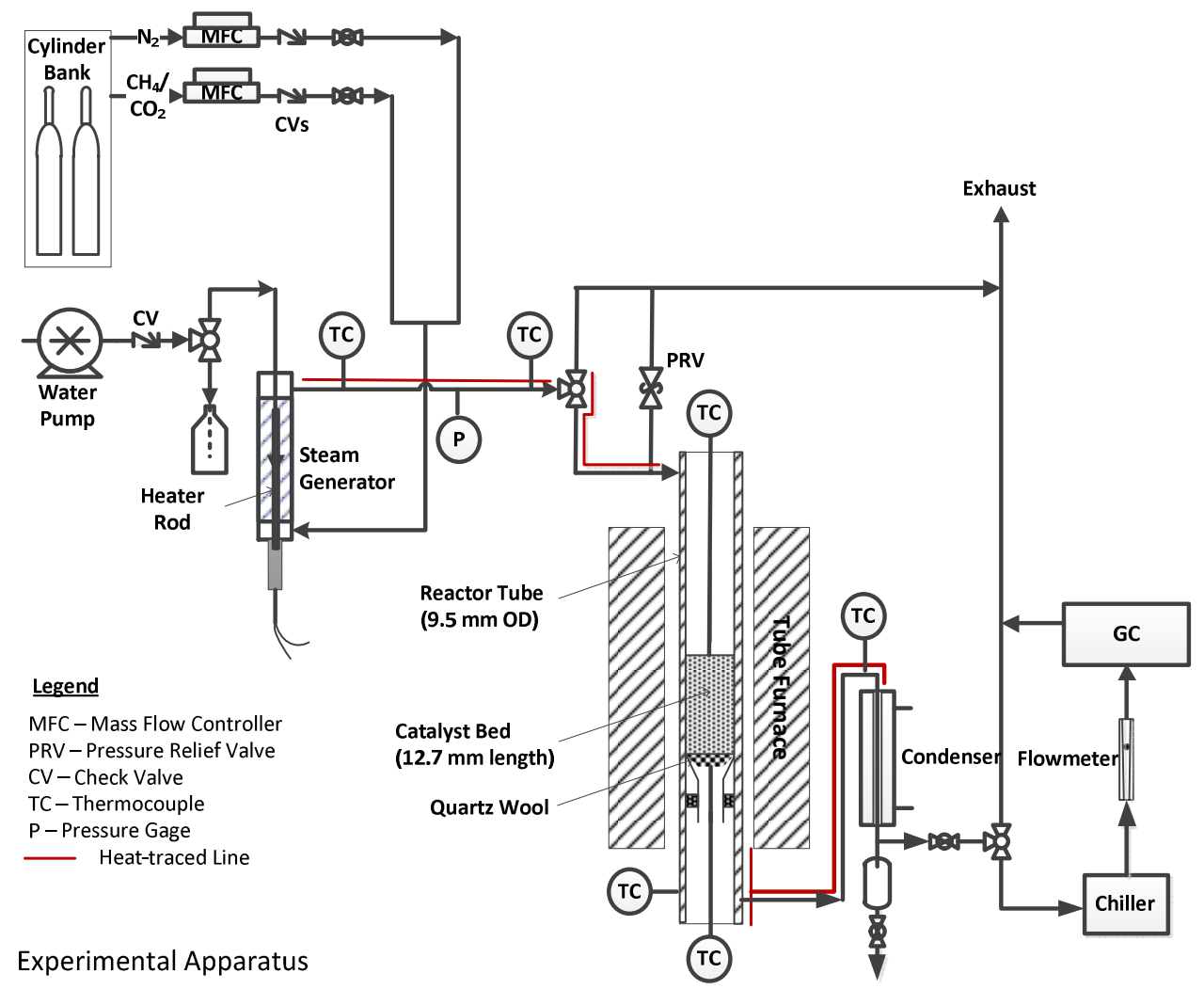

Figure 1. Micro-reactor process system used to study the steam reforming of biogas mixtures

Experimental parameters/conditions: The micro-reactor process system was operated within the following range of conditions to study their effects on the methane conversion and the product yields.

Table 2. Range of Experimental Conditions

\begin{tabular}{|l|l|}
\hline $\mathrm{CO}_{2} / \mathrm{CH}_{4}$ Feed Ratio in Biogas Mixtures & $0.55-1.51$ \\
\hline Pressure & $1-1.7 \mathrm{~atm}$ \\
\hline Catalyst Bed Exit Temperature & $590^{\circ}-685^{\circ} \mathrm{C}$ \\
\hline Steam-to-Carbon Molar Ratio, (S/C) $=\left[\mathrm{H}_{2} \mathrm{O} /\left(\mathrm{CH}_{4}+\mathrm{CO}_{2}\right)\right]$ & $1.28-3.86$ \\
\hline Gas Hourly Space Velocity (GHSV) & $9,810-27,000 \mathrm{hr}^{-1}$ \\
\hline
\end{tabular}


Where, GHSV, $\mathrm{hr}^{-1}=\frac{\text { Reactant Volumetric Flow rate, } 25^{\circ} \mathrm{C}, 1 \mathrm{~atm}, \mathrm{~cm}^{3} / \mathrm{hr}}{\text { Volume of catalyst bed, } \mathrm{cm}^{3}}$

The experimental and analytical results are evaluated in terms of the conversion and product yields, defined as follows.

$\mathrm{CH}_{4}$ or $\mathrm{CO}_{2}$ Conversion, $\%=\left(1-\frac{\mathrm{CH}_{4} \text { or } \mathrm{CO}_{2} \text { in Product, } \mathrm{mol} / \mathrm{min}}{\mathrm{CH}_{4} \text { or } \mathrm{CO}_{2} \text { in Feed, } \mathrm{mol} / \mathrm{min}}\right) \times 100$

Product Yield $\left(y_{i}\right), \mathrm{mol} /\left(\mathrm{mol}-\mathrm{CH}_{4}\right.$ in Feed $)=\frac{\text { Species } \mathrm{i} \text { in Product, } \mathrm{mol} / \mathrm{min}}{\mathrm{CH}_{4} \text { in Feed, } \mathrm{mol} / \mathrm{min}}$

Alternate $\mathrm{H}_{2}$ Yield, $\mathrm{mol} /\left(\mathrm{mol}-\mathrm{CH}_{4}+\mathrm{H}_{2} \mathrm{O}\right.$ in Feed $)=\frac{\mathrm{H}_{2} \text { in Product, } \mathrm{mol} / \mathrm{min}}{\mathrm{CH}_{4}+\mathrm{H}_{2} \mathrm{O} \text { in Feed, } \mathrm{mol} / \mathrm{min}}$ (9)

Alternate CO Yield, $\mathrm{mol} /\left(\mathrm{mol}-\mathrm{CH}_{4}+\mathrm{CO}_{2}\right.$ in Feed $)=\frac{\mathrm{CO} \text { in Product, } \mathrm{mol} / \mathrm{min}}{\mathrm{CH}_{4}+\mathrm{CO}_{2} \text { in Feed, } \mathrm{mol} / \mathrm{min}}$ (10)

\section{Results and Discussion}

\subsection{Effect of Temperature}

The effect of catalyst bed temperature was studied by varying the furnace setting to achieve gas temperatures at the catalyst bed exit in the range $590-685^{\circ} \mathrm{C}$. The feed gas was maintained with a wet gas composition of $19.4 \% \mathrm{CO}_{2}, 19.8 \% \mathrm{CH}_{4}, 51.6 \% \mathrm{H}_{2} \mathrm{O}$, and $9.2 \% \mathrm{~N}_{2}$, corresponding to a $\mathrm{CO}_{2} / \mathrm{CH}_{4}$ molar ratio of 0.98 , a steam to carbon ratio of 1.32 , and a gas hourly space velocity of 9,810 per hour.

Figure 2 shows the bed temperatures at the inlet and exit for the four furnace settings. The catalyst bed was first preheated to $\sim 600^{\circ} \mathrm{C}$, with the inlet and exit thermocouples reading $603^{\circ}$ and $595^{\circ} \mathrm{C}$, respectively. Introducing the reactants into the bed resulted in the temperatures dropping by $\sim 30$ degrees at the inlet (top) and 5 degrees at the bottom (exit). The high extents of endothermic reactions (Eqns. 1 and 2) at the inlet cause the sharp drop in temperature at the front edge. As the gas continues through the bed, it is heated again through a combination of the exothermic water gas shift (WGS) reaction (Eqn. 3) and heat transfer through the reactor wall. A similar trend, with the bed inlet being considerably cooler than at the exit, was seen as the furnace setting was raised in three additional steps, as shown in Figure 2 . The spread between the exit and inlet temperatures $\left[\Delta T=T_{\text {exit }}-T_{\text {inlet }}=15\right.$ (=590-575), 21(=636-615), 25(=663-638), $27(=685-658)]$ are seen to increase at higher furnace settings. In this temperature range, the higher bed temperatures result in more reactions, i.e., more methane steam 
reforming followed by conversion of the $\mathrm{CO}$ via water gas shift reactions. It is anticipated that this trend of increasing temperature spread would not sustain at still higher temperatures because of diminishing incremental methane conversion, and less WGS reaction since $\mathrm{CO}$ is thermodynamically favored at higher temperatures. This expectation is supported by the shrinking second derivative values $\left[\mathrm{d}(\Delta \mathrm{T}) / \mathrm{dT}_{\text {furnace }}=\right.$ $6(=21-15), 4(=25-21), 2(=27-25)]$. This anticipated trend was not confirmed in our tests because of concerns that operating at the higher temperatures may lead to catalyst deactivation and compromise the experimental plan.

Figure 3 plots the methane and carbon dioxide conversions as a function of the catalyst bed (exit) temperature. The $\mathrm{CH}_{4}$ conversion increases from $67 \%$ at $590^{\circ} \mathrm{C}$ to $93 \%$ at $685^{\circ} \mathrm{C}$. In comparison, the conversions predicted from equilibrium calculations (HSC Chemistry [27]) are higher, as indicated by the curve in Figure 3. The conversion for $\mathrm{CO}_{2}$ is negative at the lowest temperature, indicating that more $\mathrm{CO}_{2}$ is produced via the water gas shift reaction than is being consumed via $\mathrm{CO}_{2}$ reforming. While the trends for conversion and products yields are similar, a comparison of the two shows that equilibrium conversion was not achieved in the reactor, as shown in Figure 4 . The difference between the experimental and equilibrium yields is largest at the lowest temperature.

Besides insufficient residence time, a key contributing factor to the difference between the experimental and equilibrium yields is the incomplete carbon balance from the experiments. The carbon balance was $93 \%$ at $590^{\circ} \mathrm{C}$, increasing to $98 \%$ at $685^{\circ} \mathrm{C}$. The unaccounted carbon is likely due to the formation of other carbonaceous species such as $C_{2}$ and $C_{3}$ hydrocarbons, which may have been present at concentrations below the detection limits of the gas chromatograph. The improved carbon balance at the highest temperature shows a closer approach to the equilibrium values. Table 3 shows the details of these yields and related data.

Lin et. al. [28] studied biogas reforming over several catalysts and found that R67 and $\mathrm{Ni}$-Ce catalysts yielded the highest methane conversions $-95 \%$ at $700^{\circ} \mathrm{C}$, with $\mathrm{CH}_{4}: \mathrm{CO}_{2}: \mathrm{H}_{2} \mathrm{O}=3: 1: 2$. Li et. al. [18] reported data where equilibrium compositions were achieved at $800^{\circ} \mathrm{C}$ on a $\mathrm{Ni} / \mathrm{CeO}_{2}-\mathrm{ZrO}_{2}-\mathrm{Al}_{2} \mathrm{O}_{3}$ catalyst.

Table 3. Conversion and product yields from steam reforming of synthetic biogas. $\mathrm{CO}_{2} / \mathrm{CH}_{4}=0.98, \mathrm{~S} / \mathrm{C}=1.32, \mathrm{H}_{2} \mathrm{O} / \mathrm{CH}_{4}=2.6, \mathrm{GHSV}=9,810 \mathrm{hr}^{-1}$.

\begin{tabular}{|l|c|c|c|c|}
\hline Catalyst bed exit temperature, ${ }^{\circ} \mathbf{C}$ & $\mathbf{5 9 0}$ & $\mathbf{6 3 6}$ & $\mathbf{6 6 3}$ & $\mathbf{6 8 5}$ \\
\hline Equilibrium $\mathrm{CH}_{4}$ Conversion, \% & 72.1 & 87.7 & 93.4 & 96.3 \\
\hline Experimental $\mathrm{CH}_{4}$ Conversion, \% & 66.8 & 81.2 & 89.3 & 93.0 \\
\hline
\end{tabular}




\begin{tabular}{|c|c|c|c|c|}
\hline Equilibrium $\mathrm{CO}_{2}$ Conversion, $\%$ & -16.8 & -7.7 & -2.2 & 1.9 \\
\hline Experimental $\mathrm{CO}_{2}$ Conversion, $\%$ & -2.7 & 3.2 & 4.8 & 10.5 \\
\hline Equilibrium $\mathrm{CH}_{4}$ Yield, $\mathrm{mol} /\left(\mathrm{mol}-\mathrm{CH}_{4}\right.$ in Feed $)$ & 0.28 & 0.12 & 0.07 & 0.04 \\
\hline Experimental $\mathrm{CH}_{4}$ Yield, $\mathrm{mol} /\left(\mathrm{mol}-\mathrm{CH}_{4}\right.$ in Feed $)$ & $\begin{array}{c}0.33 \\
\pm 0.007\end{array}$ & $\begin{array}{c}0.19 \\
\pm 0.004\end{array}$ & $\begin{array}{c}0.11 \\
\pm 0.004\end{array}$ & $\begin{array}{c}0.07 \\
\pm 0.005\end{array}$ \\
\hline Difference $=$ Equilibrium - Experimental & -0.05 & -0.07 & -0.04 & -0.03 \\
\hline Equilibrium $\mathrm{H}_{2}$ Yield, $\mathrm{mol} /\left(\mathrm{mol}-\mathrm{CH}_{4}\right.$ in Feed) & 2.33 & 2.71 & 2.82 & 2.87 \\
\hline Experimental $\mathrm{H}_{2}$ Yield, $\mathrm{mol} /\left(\mathrm{mol}-\mathrm{CH}_{4}\right.$ in Feed $)$ & $\begin{array}{c}1.97 \\
\pm 0.015\end{array}$ & $\begin{array}{c}2.34 \\
\pm 0.009\end{array}$ & $\begin{array}{c}2.58 \\
\pm 0.018\end{array}$ & $\begin{array}{c}2.62 \\
\pm 0.019\end{array}$ \\
\hline Difference $=$ Equilibrium - Experimental & 0.36 & 0.37 & 0.24 & 0.25 \\
\hline Equilibrium $\mathrm{CO}_{2}$ Yield, $\mathrm{mol} /\left(\mathrm{mol}-\mathrm{CH}_{4}\right.$ in Feed $)$ & 1.14 & 1.05 & 1.00 & 0.96 \\
\hline Experimental $\mathrm{CO}_{2}$ Yield, $\mathrm{mol} /\left(\mathrm{mol}-\mathrm{CH}_{4}\right.$ in Feed $)$ & $\begin{array}{c}1.00 \\
\pm 0.006 \\
\end{array}$ & $\begin{array}{c}0.95 \\
\pm 0.001 \\
\end{array}$ & $\begin{array}{c}0.93 \\
\pm 0.011 \\
\end{array}$ & $\begin{array}{c}0.87 \\
\pm 0.012 \\
\end{array}$ \\
\hline Difference $=$ Equilibrium - Experimental & 0.14 & 0.10 & 0.07 & 0.09 \\
\hline Equilibrium $\mathrm{CO}$ Yield, $\mathrm{mol} /\left(\mathrm{mol}-\mathrm{CH}_{4}\right.$ in Feed $)$ & 0.56 & 0.80 & 0.91 & 0.98 \\
\hline Experimental $\mathrm{CO}$ Yield, $\mathrm{mol} /\left(\mathrm{mol}-\mathrm{CH}_{4}\right.$ in Feed $)$ & $\begin{array}{c}0.50 \\
\pm 0.022\end{array}$ & $\begin{array}{c}0.76 \\
\pm 0.004 \\
\end{array}$ & $\begin{array}{c}0.88 \\
\pm 0.017\end{array}$ & $\begin{array}{c}0.98 \\
\pm 0.027\end{array}$ \\
\hline Difference $=$ Equilibrium - Experimental & 0.06 & 0.04 & 0.03 & 0.00 \\
\hline Carbon Balance & 0.929 & 0.957 & 0.967 & 0.975 \\
\hline \multicolumn{5}{|l|}{ Experimental Yields (Eqn. 9 and 10) } \\
\hline $\mathrm{H}_{2}, \mathrm{~mol} /\left(\mathrm{mol}-\mathrm{CH}_{4}+\mathrm{H}_{2} \mathrm{O}\right.$ in Feed $)$ & 0.55 & 0.65 & 0.72 & 0.73 \\
\hline $\mathrm{CO}, \mathrm{mol} /\left(\mathrm{mol}-\mathrm{CH}_{4}+\mathrm{CO}_{2}\right.$ in Feed $)$ & 0.28 & 0.42 & 0.49 & 0.54 \\
\hline
\end{tabular}




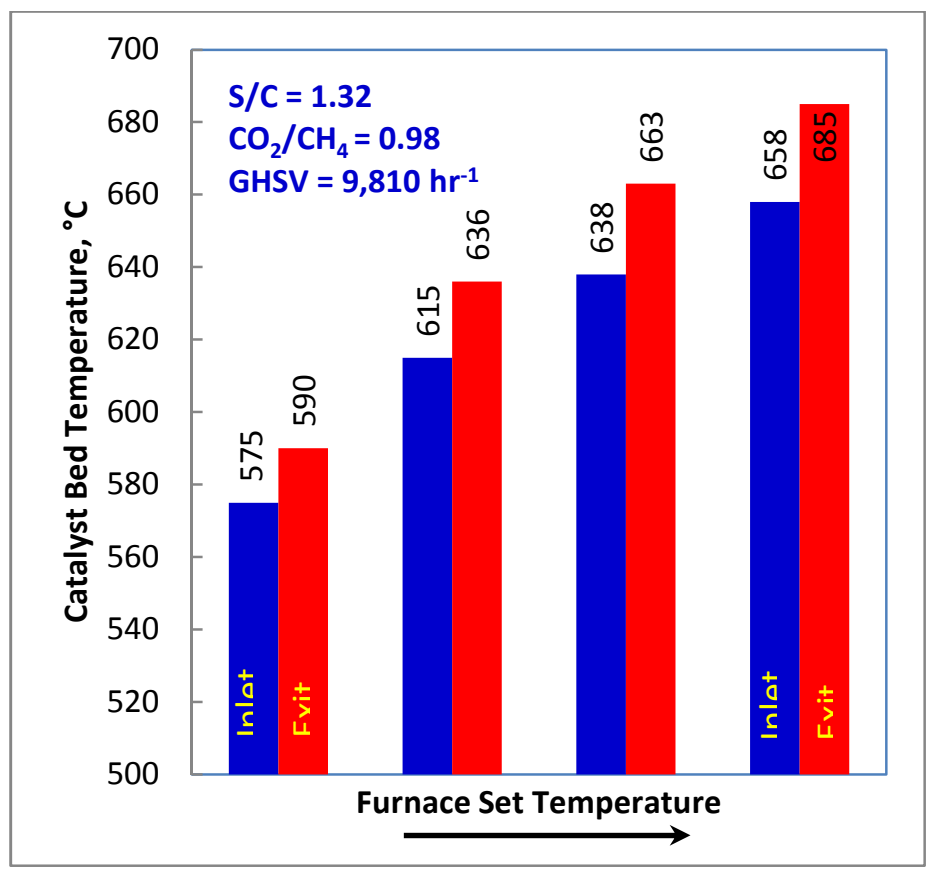

Figure 2. Catalyst bed inlet and exit temperatures for four furnace settings. $\mathrm{S} / \mathrm{C}=1.32$, $\mathrm{CO}_{2} / \mathrm{CH}_{4}=0.98, \mathrm{GHSV}=9,810 \mathrm{hr}^{-1}$.

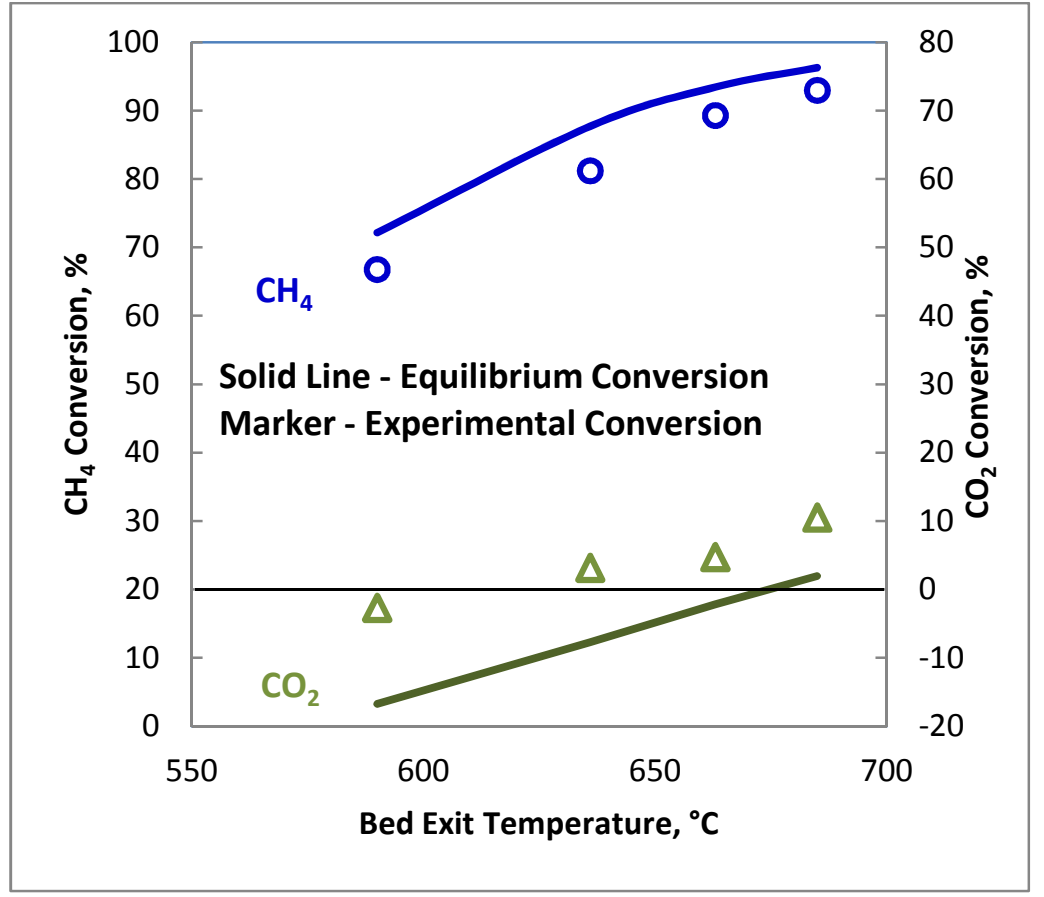

Figure 3. Effect of catalyst bed exit temperature on methane and carbon dioxide conversions. $\mathrm{S} / \mathrm{C}=1.32, \mathrm{CO}_{2} / \mathrm{CH}_{4}=0.98, \mathrm{GHSV}=9,810 \mathrm{hr}^{-1}$. 


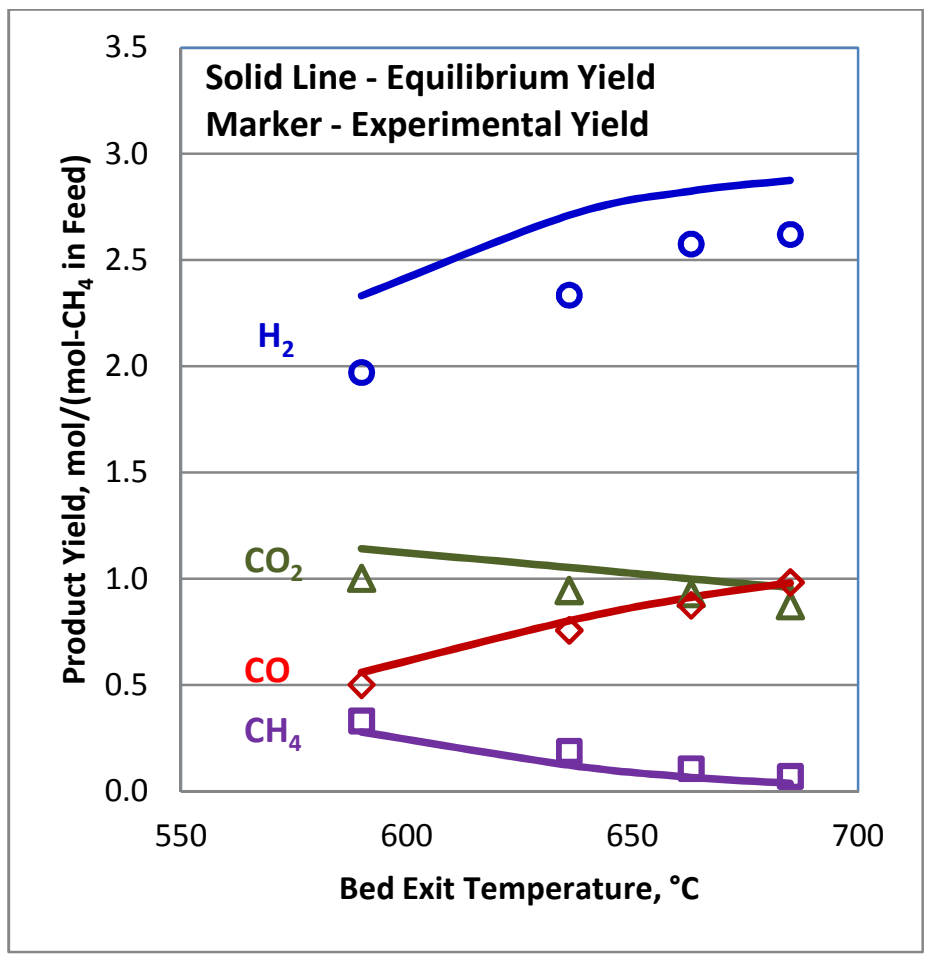

Figure 4. Effect of catalyst bed exit temperature on product yields. $\mathrm{S} / \mathrm{C}=1.32$, $\mathrm{CO}_{2} / \mathrm{CH}_{4}=0.98, \mathrm{GHSV}=9,810 \mathrm{hr}^{-1}$. 


\subsection{Effect of GHSV}

The effect of the gas hourly space velocity (GHSV) on the methane conversion and product yields was studied with the biogas mixture containing $19.4 \% \mathrm{CO}_{2}, 19.8 \% \mathrm{CH}_{4}$, $51.6 \% \mathrm{H}_{2} \mathrm{O}$, and $9.2 \% \mathrm{~N}_{2}$, corresponding to a $\mathrm{CO}_{2} / \mathrm{CH}_{4}$ molar ratio of 0.98 , and a steam to carbon ratio of 1.32 , at two catalyst bed temperature set-points of $650^{\circ} \mathrm{C}$ and $670^{\circ} \mathrm{C}$, determined from the average of the inlet and exit temperatures. The GHSV was varied from 9,810 to $27,000 \mathrm{hr}^{-1}$ (or the residence time of 0.36 to $0.13 \mathrm{~s}$ ). Figure 5 plots the catalyst bed temperatures showing the variations in the bed inlet and exit temperatures at the three space velocities. As the GHSV increased, the temperature differential between the higher exit temperatures and the lower inlet temperatures increased. This is understandable because at the higher feed rates more moles of methane participating in the endothermic reforming reactions (Eqns. 1 and 2) cool the inlet edge of the catalyst bed. In order to maintain the average catalyst bed temperatures at $\sim 650^{\circ} \mathrm{C}$ and $\sim 670^{\circ} \mathrm{C}$, the reactor temperature controller setting was adjusted (raised). The combination of higher heat transfer from the reactor wall and more CO conversion via the exothermic water gas shift reaction raised the bed exit temperature, resulting in the larger spread between the inlet and exit temperatures.

The effect of the gas hourly space velocity on the methane conversion and product yields are presented in Table 4 and Figures 6 and 7. The results show that

- Methane conversion decreased with increasing space velocities (shorter residence times), despite the higher exit temperatures at the higher space velocity. A 3 -fold increase in space velocity reduced the methane conversion by $\sim 1$ percentage point at $650^{\circ} \mathrm{C}$, and $\sim 0.5$ percentage point at $670^{\circ} \mathrm{C}$.

- Equilibrium calculations for the reactant mixture indicated conversions of $91.2 \%$ at $650^{\circ} \mathrm{C}$, and $95.8 \%$ at $680^{\circ} \mathrm{C}$. The experimental conversions at these exit temperatures were $88.4 \%$ and $92.2 \%$, respectively, confirming that the residence times were too low to achieve equilibrium.

- Increasing the bed average temperature from $650^{\circ}$ to $670^{\circ} \mathrm{C}$ increased the methane conversion by 4-5 percentage points.

- The change in product yields was more significant when the space velocity was doubled from 9,810 to 18,400 per hour.

- $\quad$ The carbon balance suggests that more of the carbon species were present in the forms of $\mathrm{CO}, \mathrm{CO}_{2}$, and $\mathrm{CH}_{4}$ at the lower space velocities and higher temperatures.

- It is reasonable to expect that since $\mathrm{CO}_{2}$ is a reactant in the $\mathrm{CO}_{2}$-reforming reaction, its yield would follow that of $\mathrm{CH}_{4}$. However, the experimental data shows the opposite, i.e., the $\mathrm{CO}_{2}$ yield increases when the $\mathrm{CH}_{4}$ yield decreases at 
the lower space velocities. This suggests that the WGS reaction which produces $\mathrm{CO}_{2}$, has a more significant effect than the $\mathrm{CO}_{2}$-reforming reaction. This trend is supported by thermodynamics which favors the WGS reaction to produce more $\mathrm{CO}_{2}$ at the lower exit temperatures, such as seen at the lower space velocities.

Chiodo et. al., [29] reported $\mathrm{CH}_{4}$ conversions of up to $70 \%$ from the reforming of a biogas mixture $\left(\mathrm{CO}_{2}: \mathrm{CH}_{4}=2: 3, \mathrm{~S} / \mathrm{C}=1.2\right)$ at a GHSV of $150,000 \mathrm{hr}^{-1}$.

Table 4. Effect of the Gas Hourly Space Velocity (GHSV) on the conversion and product yields from steam reforming of synthetic biogas. $\mathrm{CO}_{2} / \mathrm{CH}_{4}=0.98, \mathrm{~S} / \mathrm{C}=1.32$,

$\mathrm{H}_{2} \mathrm{O} / \mathrm{CH}_{4}=2.6$.

\begin{tabular}{|c|c|c|c|}
\hline & \multicolumn{3}{|c|}{ GHSV, hr ${ }^{-1}$} \\
\hline Average Temperature $=650^{\circ} \mathrm{C}$ & 9,810 & 18,400 & 27,000 \\
\hline Bed Exit Temperature, ${ }^{\circ} \mathrm{C}$ & 651 & 657 & 661 \\
\hline $\mathrm{CH}_{4}$ Conversion at $650^{\circ} \mathrm{C}, \%$ & 88.4 & 88.6 & 87.5 \\
\hline $\mathrm{H}_{2}$ Yield, $\mathrm{mol} /\left(\mathrm{mol}-\mathrm{CH}_{4}\right.$ in Feed $)$ & 2.62 & 2.54 & 2.54 \\
\hline $\mathrm{CO}_{2}$ Yield, $\mathrm{mol} /\left(\mathrm{mol}-\mathrm{CH}_{4}\right.$ in Feed $)$ & 0.98 & 0.94 & 0.95 \\
\hline $\mathrm{CO}$ Yield, $\mathrm{mol} /\left(\mathrm{mol}^{-} \mathrm{CH}_{4}\right.$ in Feed $)$ & 0.85 & 0.81 & 0.78 \\
\hline $\mathrm{CH}_{4}$ Yield, $\mathrm{mol} /\left(\mathrm{mol}-\mathrm{CH}_{4}\right.$ in Feed $)$ & 0.12 & 0.11 & 0.13 \\
\hline $\mathrm{H}_{2}, \mathrm{~mol} /\left(\mathrm{mol}-\mathrm{CH}_{4}+\mathrm{H}_{2} \mathrm{O}\right.$ in Feed $)$, Eqn. 9 & 0.73 & 0.71 & 0.71 \\
\hline $\mathrm{CO}, \mathrm{mol} /\left(\mathrm{mol}-\mathrm{CH}_{4}+\mathrm{CO}_{2}\right.$ in Feed $)$, Eqn. 10 & 0.43 & 0.41 & 0.39 \\
\hline Carbon Balance & 0.983 & 0.944 & 0.936 \\
\hline Average Temperature $=670^{\circ} \mathrm{C}$ & 9,810 & 18,400 & 27,000 \\
\hline Bed exit temperature, ${ }^{\circ} \mathrm{C}$ & 671 & 676 & 680 \\
\hline $\mathrm{CH}_{4}$ Conversion at $670^{\circ} \mathrm{C}, \%$ & 92.7 & 93.0 & 92.2 \\
\hline $\mathrm{H}_{2}$ Yield, $\mathrm{mol} /\left(\mathrm{mol}-\mathrm{CH}_{4}\right.$ in Feed) & 2.70 & 2.60 & 2.56 \\
\hline $\mathrm{CO}_{2}$ Yield, $\mathrm{mol} /\left(\mathrm{mol}-\mathrm{CH}_{4}\right.$ in Feed $)$ & 0.95 & 0.93 & 0.93 \\
\hline $\mathrm{CO}$ Yield, $\mathrm{mol} /\left(\mathrm{mol}^{-} \mathrm{CH}_{4}\right.$ in Feed $)$ & 0.93 & 0.85 & 0.80 \\
\hline $\mathrm{CH}_{4}$ Yield, $\mathrm{mol} /\left(\mathrm{mol}-\mathrm{CH}_{4}\right.$ in Feed $)$ & 0.076 & 0.086 & 0.106 \\
\hline $\mathrm{H}_{2}, \mathrm{~mol} /\left(\mathrm{mol}-\mathrm{CH}_{4}+\mathrm{H}_{2} \mathrm{O}\right.$ in Feed $)$, Eqn. 9 & 0.75 & 0.72 & 0.71 \\
\hline $\mathrm{CO}, \mathrm{mol} /\left(\mathrm{mol}-\mathrm{CH}_{4}+\mathrm{CO}_{2}\right.$ in Feed $)$, Eqn. 10 & 0.47 & 0.43 & 0.40 \\
\hline Carbon Balance & 0.986 & 0.947 & 0.935 \\
\hline
\end{tabular}




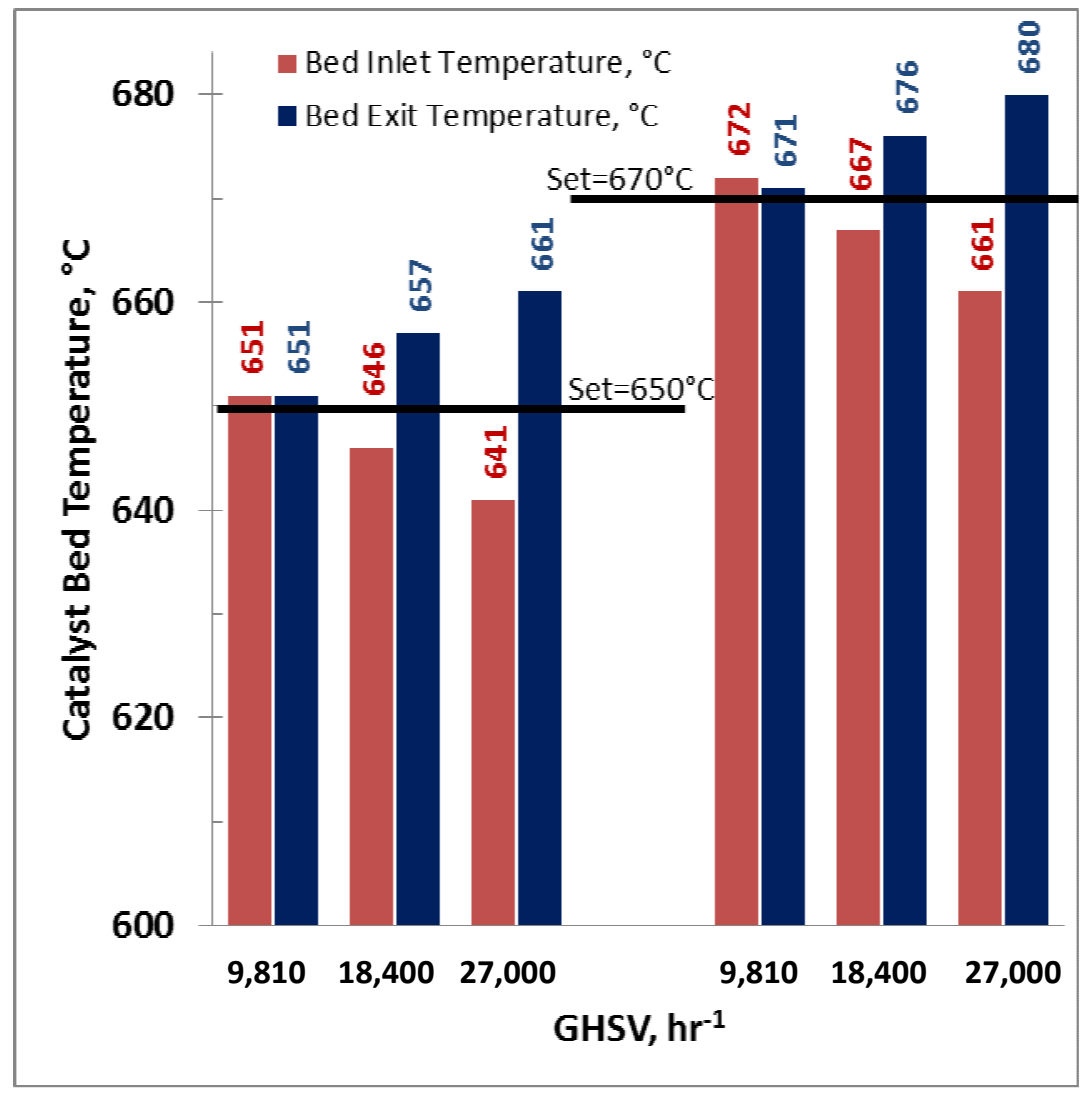

Figure 5. Effect of gas hourly space velocity (GHSV) on catalyst bed inlet and exit temperatures. $\mathrm{S} / \mathrm{C}=1.32, \mathrm{CO}_{2} / \mathrm{CH}_{4}=0.98$. 


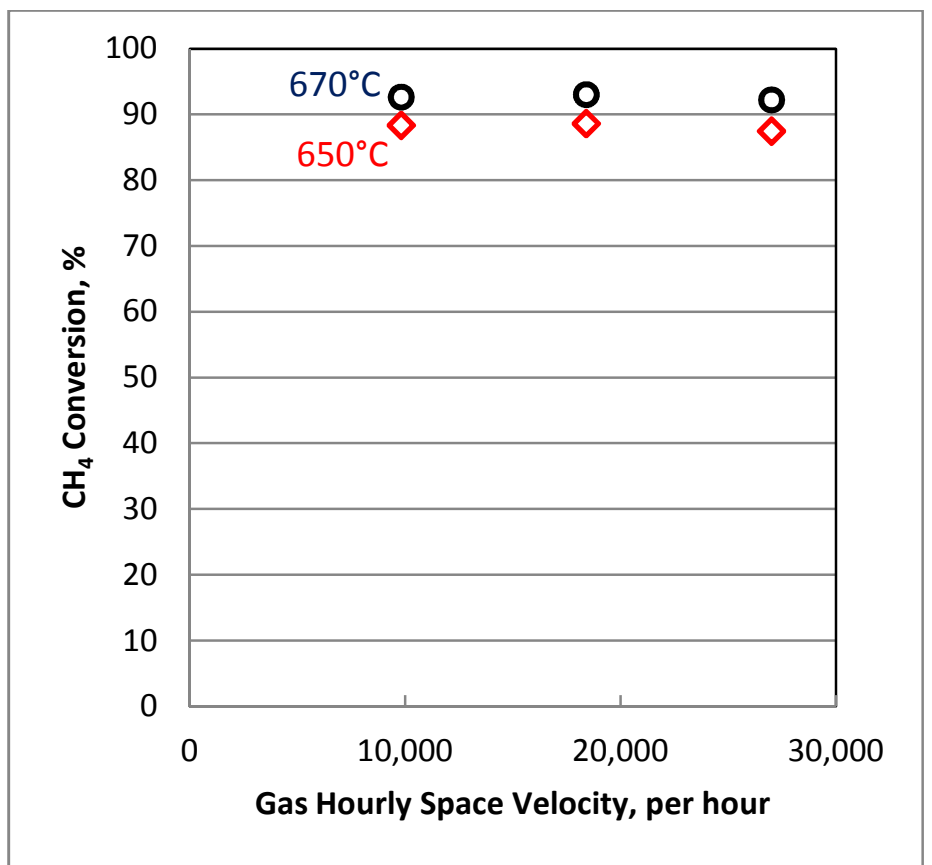

Figure 6. Effect of gas hourly space velocity (GHSV) on methane conversion. S/C=1.32, $\mathrm{CO}_{2} / \mathrm{CH}_{4}=0.98, \mathrm{~T}=650^{\circ} \mathrm{C}, 670^{\circ} \mathrm{C}$.

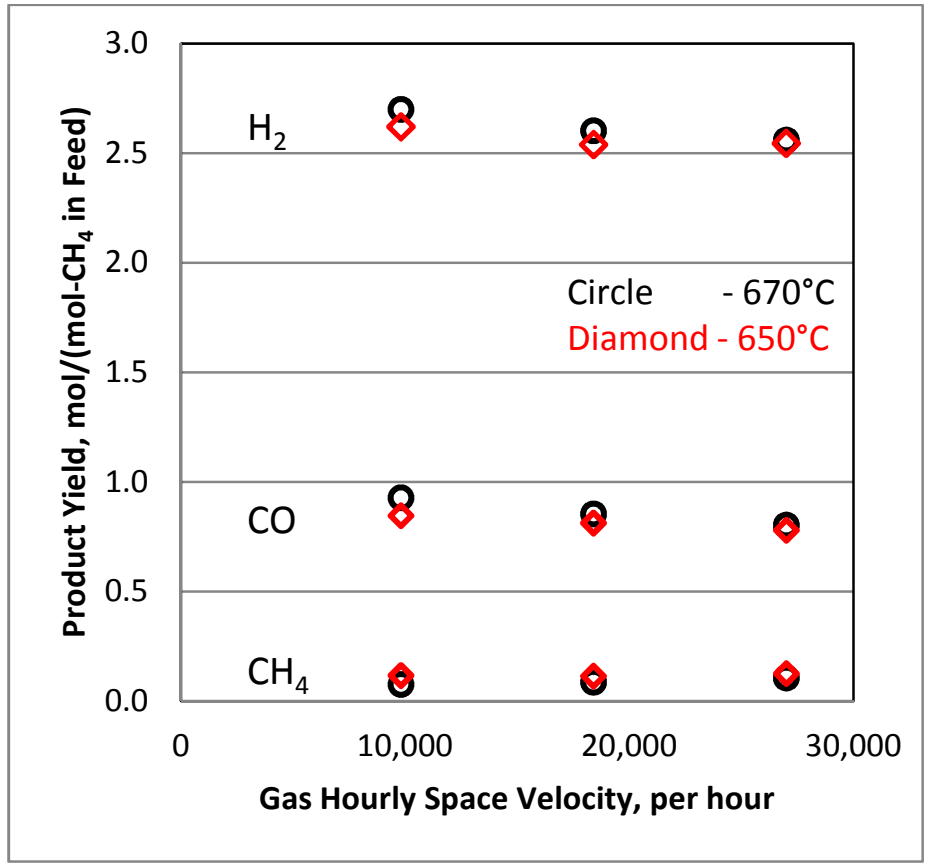

Figure 7. Effect of gas hourly space velocity (GHSV) on product yields. $\mathrm{S} / \mathrm{C}=1.32$, $\mathrm{CO}_{2} / \mathrm{CH}_{4}=0.98, \mathrm{~T}=650^{\circ} \mathrm{C}, 670^{\circ} \mathrm{C}$. 


\subsection{Effect of Steam-to-Carbon (S/C) Molar Ratio in the Feed}

The steam-to-carbon molar ratio $\left(\mathrm{H}_{2} \mathrm{O} /\left(\mathrm{CH}_{4}+\mathrm{CO}_{2}\right)\right)$ in the reactant stream should affect the steam reforming [Eq. 1] and the water gas shift [Eq. 3] reactions. This effect was studied with the biogas feed mixture with a $\mathrm{CO}_{2} / \mathrm{CH}_{4}$ molar ratio of 0.98 , maintained at a flow rate of $38.3 \mathrm{ml} / \mathrm{min}$. The internal standard, nitrogen, was maintained at $9 \mathrm{ml} / \mathrm{min}$. The steam feed rate was adjusted to deliver $\mathrm{S} / \mathrm{C}$ ratios of $1.32,2.59$, and 3.87. Because of the change in the steam flow rate, the corresponding GHSV were $9,810,14,700$, and $19,600 \mathrm{hr}^{-1}$, respectively. The $\mathrm{H}_{2} \mathrm{O} / \mathrm{CH}_{4}(\mathrm{~S} / \mathrm{M})$ molar ratio varied between 2.60 to 7.64 , while the $\mathrm{O} / \mathrm{C}$ ratio varied between 2.31 to 4.85 . Table 5 summarizes these test variables and detailed results of methane conversion and product yields.

Figure 8 shows the plots of methane and $\mathrm{CO}_{2}$ conversions as a function of the $\mathrm{S} / \mathrm{C}$ molar ratio at two furnace settings corresponding to bed exit temperatures of $650^{\circ} \mathrm{C}$ and $625^{\circ} \mathrm{C}$. Doubling the steam content increases the methane conversion by 11.9 percentage points at $625^{\circ} \mathrm{C}$; increasing it 3-fold increases the conversion to $97.5 \%$ and $99 \%$ at $625^{\circ} \mathrm{C}$ and $650^{\circ} \mathrm{C}$, respectively. The $\mathrm{CO}_{2}$ conversion plotted in Figure 8 shows negative values (or $\mathrm{CO}_{2}$ production) at all points tested, except at $\mathrm{S} / \mathrm{C}=1.32,650^{\circ} \mathrm{C}$, confirming that higher $\mathrm{S} / \mathrm{C}$ and lower temperatures favor $\mathrm{CO}_{2}$ formation via the water gas shift reaction. Effendi et. al. [19] reports on the effect of steam over a broader range with a maximum of $\sim 75 \% \mathrm{CO}_{2}$ conversion at $750^{\circ} \mathrm{C}$, and a feed gas to steam ratio of 1.8 . Figure 9 shows the effect of the $\mathrm{S} / \mathrm{C}$ molar ratio on the product gas yields for the two reactor temperatures. Adding steam enables of the steam reforming reaction which reduces the unreacted methane yields, which adds $\mathrm{H}_{2}$ and $\mathrm{CO}$ into the product gas. The presence of additional steam further converts the $\mathrm{CO}$ via the water gas shift reaction to increase the $\mathrm{H}_{2}$ and $\mathrm{CO}_{2}$ yields. Thus added steam increases the $\mathrm{H}_{2}$ and $\mathrm{CO}_{2}$ yields while reducing the $\mathrm{CO}$ yield as shown in Fig. 9.

For any given temperature, the results seen in Table 5 and Figures 8-9 reflect the changes of both the $\mathrm{S} / \mathrm{C}$ molar ratio and the GHSV. To see the effect of only the $\mathrm{S} / \mathrm{C}$ ratio, the conversions for the higher steam flow rates were corrected for the GHSV effects. This was achieved by compensating for the loss in conversion due to the higher GHSV (with respect to $9,810 \mathrm{hr}^{-1}$ ) by applying the curve fit correlation from the data in the previous section (Effect of GHSV), using the data at $650^{\circ} \mathrm{C}$. The calculations reveal that operating at $9,810 \mathrm{hr}^{-1}$ (instead of the higher values at the higher $\mathrm{S} / \mathrm{Cs}$ ) would increase the conversion by 0.3 and 0.5 (as given in Table 5) percentage points at $\mathrm{S} / \mathrm{C}=2.59$ and 3.87 , respectively. Thus, the conversion at $650^{\circ} \mathrm{C}, \mathrm{S} / \mathrm{C}=3.87$, and GHSV $=9,810 \mathrm{hr}^{-1}$ can be expected to exceed $99.5 \%$.

Equilibrium calculations for the feed gas mixture at $650^{\circ} \mathrm{C}$ reveal that the experimental yields approached the equilibrium values at the highest $\mathrm{S} / \mathrm{C}$ of 3.87, as shown in Table 5 . 
Table 5. Effect of the steam-to-carbon molar ratio (S/C) in the feed gas on the conversion and product yields from steam reforming of synthetic biogas.

$\mathrm{CO}_{2} / \mathrm{CH}_{4}=0.98$, Bed Exit Temperature $=625^{\circ} \mathrm{C}, 650^{\circ} \mathrm{C}$.

\begin{tabular}{|c|c|c|c|}
\hline $\mathrm{H}_{2} \mathrm{O} /\left(\mathrm{CO}_{2}+\mathrm{CH}_{4}\right)$ in Feed, $\mathrm{S} / \mathrm{C}$ molar ratio & 1.32 & 2.59 & 3.87 \\
\hline $\mathrm{H}_{2} \mathrm{O} / \mathrm{CH}_{4}$ in Feed, $\mathrm{S} / \mathrm{M}$ molar ratio & 2.60 & 5.12 & 7.64 \\
\hline $\mathrm{O} / \mathrm{C}$ in Feed, atomic ratio & 2.31 & 3.58 & 4.85 \\
\hline GHSV, $\mathrm{hr}^{-1}$ & 9,810 & 14,700 & 19,600 \\
\hline $\mathrm{CO}_{2}$ Conversion $\left(650^{\circ} \mathrm{C}\right), \%$ & 4.9 & -32.1 & -47.6 \\
\hline $\mathrm{CH}_{4}$ Conversion $\left(650^{\circ} \mathrm{C}\right), \%$ & 87.2 & 96.5 & 99.0 \\
\hline $\mathrm{CH}_{4}$ Conversion Corrected $\left(650^{\circ} \mathrm{C}\right)$ for $\mathrm{GHSV}=9,810 \mathrm{hr}^{-1}$ & 87.2 & 96.8 & 99.5 \\
\hline Equilibrium $\mathrm{CH}_{4}$ Conversion $\left(650^{\circ} \mathrm{C}\right), \%$ & 90.8 & 97.5 & 99.2 \\
\hline \multicolumn{4}{|l|}{ Experimental Product Yields $\left(650^{\circ} \mathrm{C}\right), \%$} \\
\hline $\mathrm{H}_{2}, \mathrm{~mol} /\left(\mathrm{mol}-\mathrm{CH}_{4}\right.$ in Feed $)$ & 2.49 & 3.23 & 3.47 \\
\hline $\mathrm{CO}_{2}, \mathrm{~mol} /\left(\mathrm{mol}-\mathrm{CH}_{4}\right.$ in Feed $)$ & 0.93 & 1.29 & 1.44 \\
\hline $\mathrm{CO}, \mathrm{mol} /\left(\mathrm{mol}-\mathrm{CH}_{4}\right.$ in Feed $)$ & 0.82 & 0.59 & 0.4 \\
\hline $\mathrm{CH}_{4}, \mathrm{~mol} /\left(\mathrm{mol}-\mathrm{CH}_{4}\right.$ in Feed $)$ & 0.13 & 0.04 & 0.01 \\
\hline $\mathrm{H}_{2}, \mathrm{~mol} /\left(\mathrm{mol}-\mathrm{CH}_{4}+\mathrm{H}_{2} \mathrm{O}\right.$ in Feed $)$, Eqn. 9 & 0.69 & 0.53 & 0.40 \\
\hline $\mathrm{CO}, \mathrm{mol} /\left(\mathrm{mol}-\mathrm{CH}_{4}+\mathrm{CO}_{2}\right.$ in Feed $)$, Eqn. 10 & 0.41 & 0.30 & 0.20 \\
\hline Carbon Balance $\left(650^{\circ} \mathrm{C}\right)$ & 0.950 & 0.967 & 0.937 \\
\hline \multicolumn{4}{|l|}{ Equilibrium Yields $\left(650^{\circ} \mathrm{C}\right)$} \\
\hline $\mathrm{H}_{2}, \mathrm{~mol} /\left(\mathrm{mol}-\mathrm{CH}_{4}\right.$ in Feed $)$ & 2.77 & 3.30 & 3.53 \\
\hline $\mathrm{CO}_{2}, \mathrm{~mol} /\left(\mathrm{mol}-\mathrm{CH}_{4}\right.$ in Feed $)$ & 1.03 & 1.36 & 1.53 \\
\hline $\mathrm{CO}, \mathrm{mol} /\left(\mathrm{mol}-\mathrm{CH}_{4}\right.$ in Feed $)$ & 0.86 & 0.59 & 0.44 \\
\hline $\mathrm{CH}_{4}, \mathrm{~mol} /\left(\mathrm{mol}-\mathrm{CH}_{4}\right.$ in Feed $)$ & 0.09 & 0.03 & 0.01 \\
\hline $\mathrm{CO}_{2}$ Conversion $\left(625^{\circ} \mathrm{C}\right), \%$ & -7.1 & -33.9 & -49.0 \\
\hline $\mathrm{CH}_{4}$ Conversion $\left(625^{\circ} \mathrm{C}\right), \%$ & 81.8 & 93.7 & 97.5 \\
\hline \multicolumn{4}{|l|}{ Experimental Product Yields $\left(625^{\circ} \mathrm{C}\right)$} \\
\hline $\mathrm{H}_{2}, \mathrm{~mol} /\left(\mathrm{mol}-\mathrm{CH}_{4}\right.$ in Feed $)$ & 2.51 & 3.14 & 3.45 \\
\hline $\mathrm{CO}_{2}, \mathrm{~mol} /\left(\mathrm{mol}-\mathrm{CH}_{4}\right.$ in Feed $)$ & 1.05 & 1.31 & 1.46 \\
\hline $\mathrm{CO}, \mathrm{mol} /\left(\mathrm{mol}-\mathrm{CH}_{4}\right.$ in Feed $)$ & 0.71 & 0.50 & 0.39 \\
\hline $\mathrm{CH}_{4}, \mathrm{~mol} /\left(\mathrm{mol}-\mathrm{CH}_{4}\right.$ in Feed $)$ & 0.18 & 0.06 & 0.03 \\
\hline $\mathrm{H}_{2}, \mathrm{~mol} /\left(\mathrm{mol}-\mathrm{CH}_{4}+\mathrm{H}_{2} \mathrm{O}\right.$ in Feed $)$, Eqn. 9 & 0.70 & 0.51 & 0.40 \\
\hline $\mathrm{CO}, \mathrm{mol} /\left(\mathrm{mol}-\mathrm{CH}_{4}+\mathrm{CO}_{2}\right.$ in Feed), Eqn. 10 & 0.36 & 0.25 & 0.20 \\
\hline Carbon Balance $\left(625^{\circ} \mathrm{C}\right)$ & 0.979 & 0.948 & 0.947 \\
\hline \multicolumn{4}{|l|}{ Equilibrium Yields $\left(625^{\circ} \mathrm{C}\right)$} \\
\hline $\mathrm{H}_{2}, \mathrm{~mol} /\left(\mathrm{mol}-\mathrm{CH}_{4}\right.$ in Feed $)$ & 2.60 & 3.26 & 3.53 \\
\hline $\mathrm{CO}_{2}, \mathrm{~mol} /\left(\mathrm{mol}-\mathrm{CH}_{4}\right.$ in Feed $)$ & 1.08 & 1.39 & 1.56 \\
\hline $\mathrm{CO}, \mathrm{mol} /\left(\mathrm{mol}-\mathrm{CH}_{4}\right.$ in Feed $)$ & 0.74 & 0.53 & 0.40 \\
\hline $\mathrm{CH}_{4}, \mathrm{~mol} /\left(\mathrm{mol}-\mathrm{CH}_{4}\right.$ in Feed $)$ & 0.17 & 0.05 & 0.02 \\
\hline
\end{tabular}




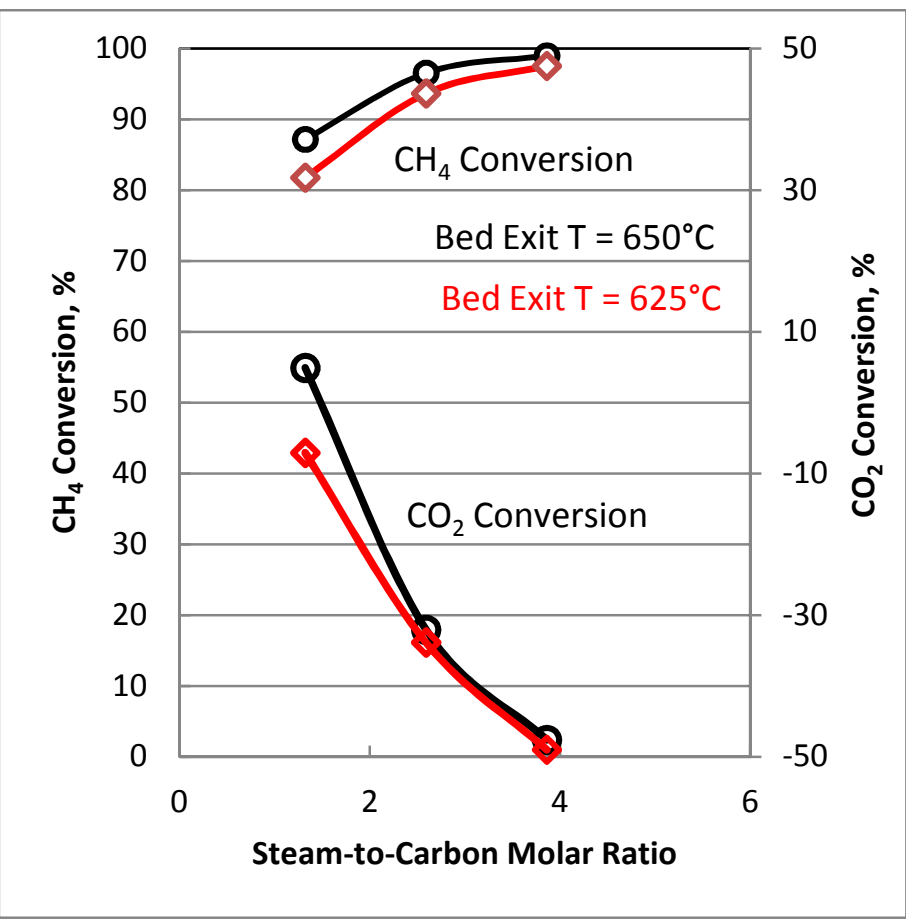

Figure 8. Effect of the steam-to-carbon molar ratio on methane and carbon dioxide conversions. $\mathrm{CO}_{2} / \mathrm{CH}_{4}=0.98, \mathrm{~T}=650^{\circ} \mathrm{C}, 625^{\circ} \mathrm{C}$.

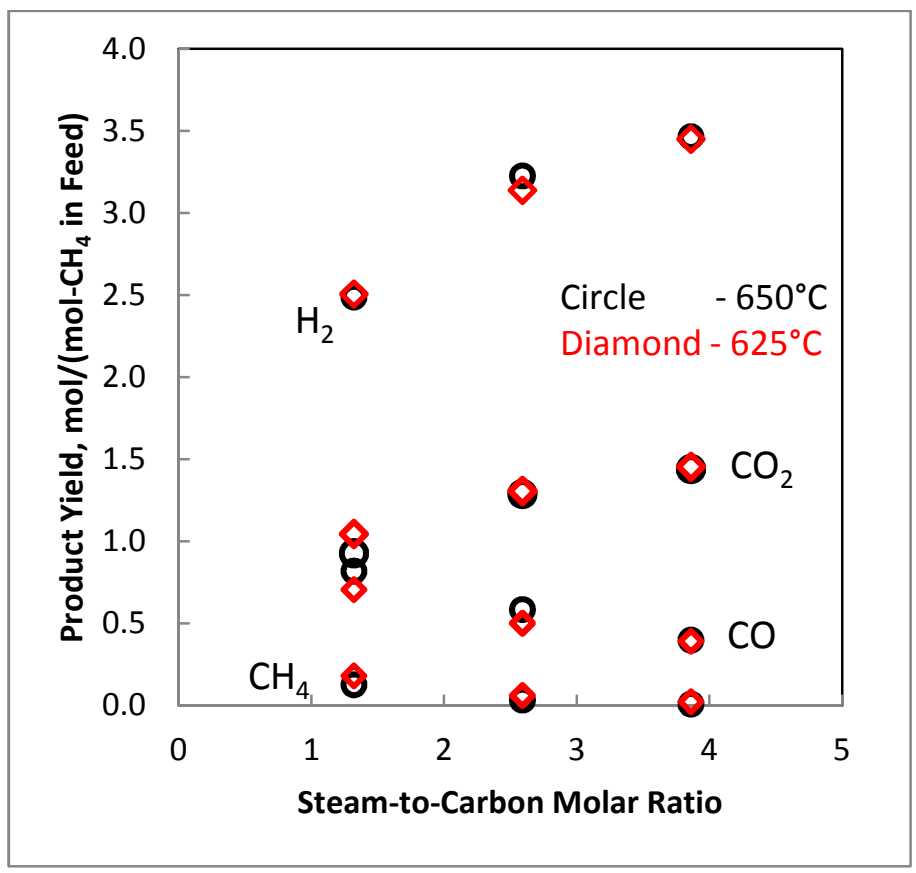

Figure 9. Effect of the steam-to-carbon molar ratio on product yields. $\mathrm{CO}_{2} / \mathrm{CH}_{4}=0.98$, $\mathrm{T}=650^{\circ} \mathrm{C}, 625^{\circ} \mathrm{C}$. 


\subsection{Effect of $\mathrm{CO}_{2} / \mathrm{CH}_{4}$ Molar Ratio in the Feed}

Biogas contains varying concentrations of carbon dioxide, which affects the reforming process via the $\mathrm{CO}_{2}$-reforming, the water gas shift, and the Boudouard reactions. The effect of the $\mathrm{CO}_{2} / \mathrm{CH}_{4}$ molar ratio was studied by varying the ratio between 0.55 and 1.51. The reactor exit temperature was maintained at $\sim 650^{\circ} \mathrm{C}$. Two sets of experiments were conducted: (i) the $\mathrm{S} / \mathrm{C}$ molar ratio in the feed gas was held constant at 1.28 and GHSV $=9,930 \mathrm{hr}^{-1}$, and (ii) the $\mathrm{O} / \mathrm{C}\left(\left[\mathrm{H}_{2} \mathrm{O}+2 * \mathrm{CO}_{2}\right] /\left[\mathrm{CH}_{4}+\mathrm{CO}_{2}\right]\right)$ in the feed gas was held constant at 2.26; for this set the GHSV changed from $9,200 \mathrm{hr}^{-1}(\mathrm{~S} / \mathrm{C}=1.55$, $\left.\mathrm{CO}_{2} / \mathrm{CH}_{4}=0.55\right)$ to $10,800 \mathrm{hr}^{-1}$ (S/C=1.06, $\mathrm{CO}_{2} / \mathrm{CH}_{4}=1.51$ ).

Figure 10 shows the effect of $\mathrm{CO}_{2} / \mathrm{CH}_{4}$ molar ratio on methane and carbon dioxide conversions. Both conversions increase with increasing $\mathrm{CO}_{2} / \mathrm{CH}_{4}$ ratio in the feed. The effect of constant $\mathrm{S} / \mathrm{C}=1.28$ on both methane and $\mathrm{CO}_{2}$ conversions are more pronounced (as indicated by the slopes) than that seen for the constant $\mathrm{O} / \mathrm{C}=2.26$. One explanation for this is that at constant $\mathrm{O} / \mathrm{C}$ experiments, the $\mathrm{S} / \mathrm{C}$ molar ratios decreases from 1.55 to 1.06 as the $\mathrm{CO}_{2} / \mathrm{CH}_{4}$ increases from 0.55 to 1.51 ; thus the lower steam content reduces the $\mathrm{SMR}$ reaction and the methane conversion. The effect of the $\mathrm{CO}_{2} / \mathrm{CH}_{4}$ molar ratio on the $\mathrm{CO}_{2}$ conversions is even more distinct. At low ratios, the $\mathrm{CO}_{2}$ conversion is negative indicating that more $\mathrm{CO}_{2}$ is produced as a result of the methane steam reforming and water gas shift reactions than that consumed by the $\mathrm{CO}_{2-}$ reforming and the reverse water gas shift reactions. The slopes of the data points indicate that the effect at constant $\mathrm{S} / \mathrm{C}=1.28$ is more pronounced than that at constant $\mathrm{O} / \mathrm{C}=2.26$.

Figure 11 shows the effect on the $\mathrm{H}_{2}$ and $\mathrm{CO}$ product yields. The $\mathrm{H}_{2}$ yield changes little as a result of increasing the $\mathrm{CO}_{2}$ in the feed, even though the $\mathrm{CH}_{4}$ conversion (produces $\mathrm{H}_{2}$ ) was seen to increase in the previous figure. This is possible because the addition of $\mathrm{CO}_{2}$ in the feed favors the reverse WGS reaction (consumes $\mathrm{H}_{2}$ via $\mathrm{CO}_{2}+\mathrm{H}_{2}=\mathrm{CO}+\mathrm{H}_{2} \mathrm{O}$ ). The effect of the added $\mathrm{CO}_{2}$ on the $\mathrm{CO}$ yield is readily observed, showing higher $\mathrm{CO}$ yields resulting from a combination of $\mathrm{CH}_{4}$ ( $\mathrm{CO}_{2}$-reforming) conversion and the reverse WGS reactions. The total moles of $\mathrm{H}_{2}+\mathrm{CO}$ produced at a $\mathrm{CO}_{2} / \mathrm{CH}_{4}=1.51$ at constant $\mathrm{O} / \mathrm{C}$ is 3.42, which is $\sim 10 \%$ higher than the value of 3.06 at $\mathrm{CO}_{2} / \mathrm{CH}_{4}=0.55$ at constant $\mathrm{O} / \mathrm{C}$.

It is reasonable to wonder what proportion of the $\mathrm{CO}$ produced is derived from $\mathrm{CO}_{2}$. If is an acceptable assumption that all the $\mathrm{CH}_{4}$ converted produces $\mathrm{CO}$, and any excess moles are derived from $\mathrm{CO}_{2}$ via $\mathrm{CO}_{2}$-reforming and/or reverse water gas shift reactions. The assumption is weakened by the fact that the carbon balance is less than $100 \%$ and the other carbonaceous species not accounted in the analysis could be derived from either $\mathrm{CH}_{4}$ or $\mathrm{CO}_{2}$. Proceeding with the assumption, the amount of $\mathrm{CO}$ produced from $\mathrm{CO}_{2}$ is 
plotted against the $\mathrm{CO}_{2} / \mathrm{CH}_{4}$ ratio in Figure 12, for the two sets of experiments conducted with constant $\mathrm{O} / \mathrm{C}=2.26$ and $\mathrm{S} / \mathrm{C}=1.28$.

For the constant $\mathrm{O} / \mathrm{C}$ ratio experiments, $\mathrm{CO}_{2}$ is converted to produce $\mathrm{CO}$ only at the highest $\mathrm{CO}_{2} / \mathrm{CH}_{4}$ ratio where the $\mathrm{S} / \mathrm{C}$ is also the lowest; all other points where the $\mathrm{S} / \mathrm{C}$ is higher show a negative production of $\mathrm{CO}$, i.e., conversion of $\mathrm{CO}$ from $\mathrm{SMR}$ to $\mathrm{CO}_{2}$ via WGS. Since the $\mathrm{C}$ and $\mathrm{O}$ feeds remain constant in this experimental set, the $\mathrm{CO}$ production / consumption shows a linear relationship with increasing $\mathrm{CO}_{2}$ content in the feed. The data shows that $\mathrm{CO}_{2}$ is converted to $\mathrm{CO}$ only at a high $\mathrm{CO}_{2} / \mathrm{CH}_{4}$ ratio - in this case at $\mathrm{CO}_{2} / \mathrm{CH}_{4}>\sim 1.4, \mathrm{O} / \mathrm{C}=2.26$ and $\mathrm{S} / \mathrm{C}=1.10$.

In the case of the constant S/C experiments, there is no obvious trend because the number of $\mathrm{O} / \mathrm{C}$ ratio increased with increasing $\mathrm{CO}_{2}$ in the feed, thereby favoring $\mathrm{CO}_{2}$ yields over $\mathrm{CO}$.

It is worth noting that the presence of $\mathrm{CO}_{2}$ in the biogas is advantageous when the desired product is syngas $\left(\mathrm{H}_{2}+\mathrm{CO}\right)$ that is used to produce higher value products such as synthetic liquid fuels or other chemicals. However, when the desired product is hydrogen, much of the $\mathrm{CO}$ produced is converted back to $\mathrm{CO}_{2}$ in a downstream WGS reactor, and therefore adds no benefit.

Table 6 lists the details of the effect of the $\mathrm{CO}_{2} / \mathrm{CH}_{4}$ molar ratio, for the two sets of experiments. 


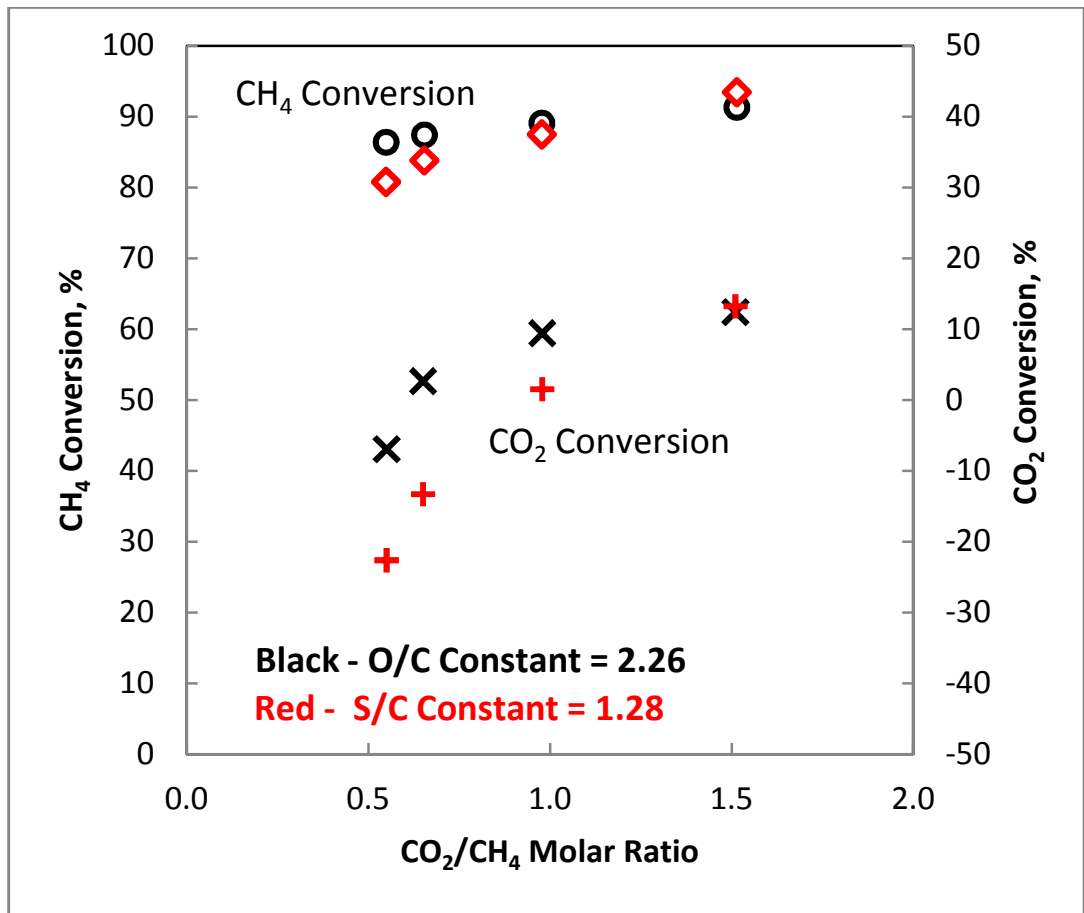

Figure 10. Effect of the $\mathrm{CO}_{2} / \mathrm{CH}_{4}$ molar ratio on $\mathrm{CH}_{4}$ and $\mathrm{CO}_{2}$ conversions. Catalyst bed exit temperature, $650^{\circ} \mathrm{C}$. 


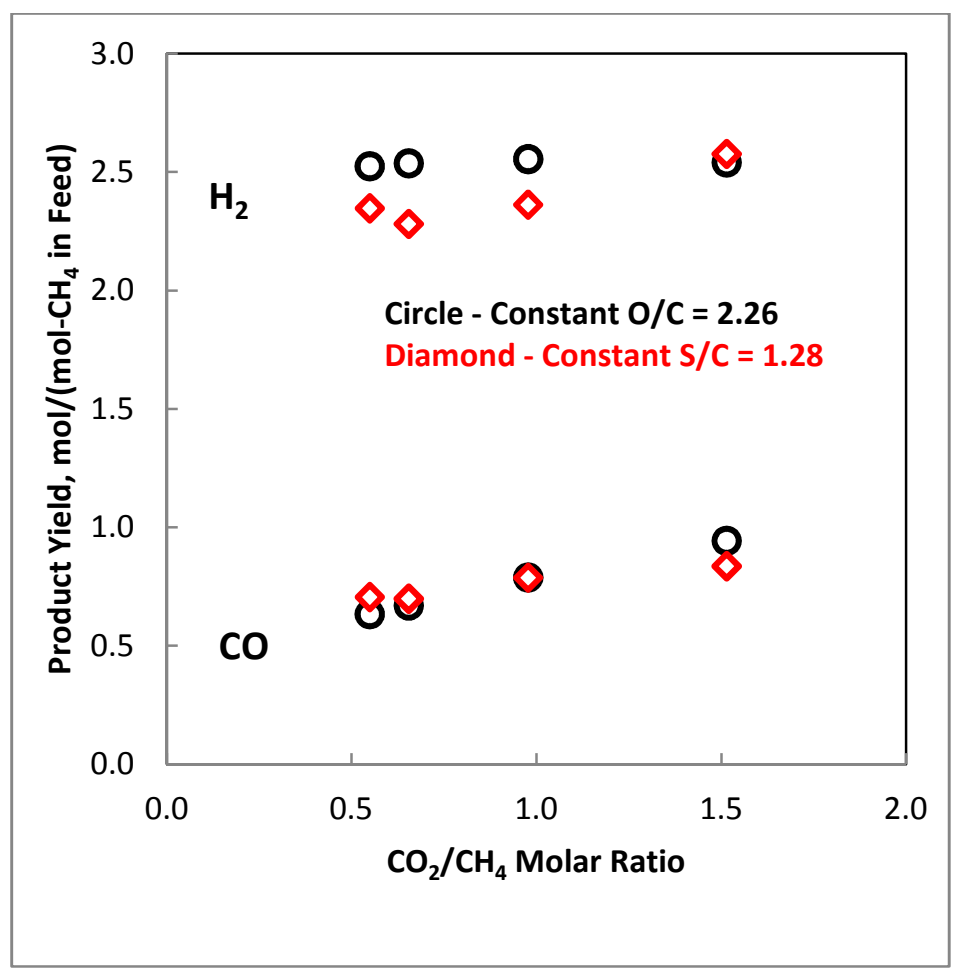

Figure 11. Effect of the $\mathrm{CO}_{2} / \mathrm{CH}_{4}$ on hydrogen and carbon monoxide product yields. Catalyst bed exit temperature, $650^{\circ} \mathrm{C}$.

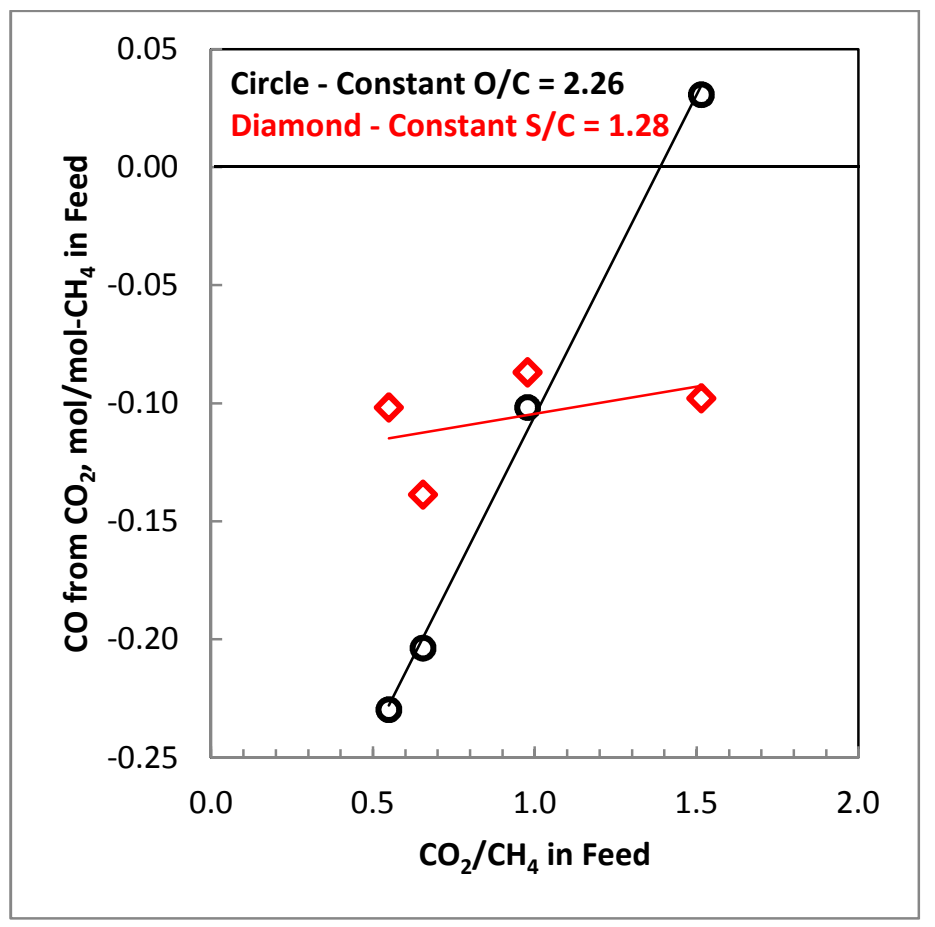

Figure 12. Effect of the $\mathrm{CO}_{2} / \mathrm{CH}_{4}$ ratios in the feed gas on the production of $\mathrm{CO}$ from $\mathrm{CO}_{2}$ at constant $\mathrm{O} / \mathrm{C}$ or constant $\mathrm{S} / \mathrm{C}$. Catalyst bed exit temperature, $650^{\circ} \mathrm{C}$. 
Table 6. Effect of the $\mathrm{CO}_{2} / \mathrm{CH}_{4}$ molar ratio in the feed gas on the conversion and product yields from reforming of synthetic biogas. Bed Exit Temperature $=650^{\circ} \mathrm{C}$.

\begin{tabular}{|c|c|c|c|c|}
\hline $\mathrm{CO}_{2} / \mathrm{CH}_{4}$ Ratio in Feed gas, molar ratio & 1.51 & 0.98 & 0.65 & 0.55 \\
\hline $\mathrm{S} / \mathrm{C}, \mathrm{H}_{2} \mathrm{O} /\left(\mathrm{CO}+\mathrm{CH}_{4}\right)$ in Feed, molar ratio & \multicolumn{4}{|c|}{1.28} \\
\hline $\mathrm{O} / \mathrm{C}$ in Feed, atomic ratio & 2.48 & 2.26 & 2.07 & 1.98 \\
\hline $\mathrm{H}_{2} \mathrm{O} / \mathrm{CH}_{4}$ in Feed, $\mathrm{S} / \mathrm{M}$, molar ratio & 3.21 & 2.52 & 2.11 & 1.97 \\
\hline $\mathrm{O} / \mathrm{CH}_{4}$ in Feed, atomic ratio & 6.23 & 4.48 & 3.42 & 3.07 \\
\hline GHSV, hr ${ }^{-1}$ & \multicolumn{4}{|c|}{9,930} \\
\hline $\mathrm{CH}_{4}$ Conversion, $\%$ & 93.5 & 87.5 & 83.8 & 80.8 \\
\hline Equilibrium Conversion $\left(650^{\circ} \mathrm{C}\right)$ & 93.9 & 89.6 & 85.1 & 83.1 \\
\hline \multicolumn{5}{|l|}{ Experimental Product Yields $\left(650^{\circ} \mathrm{C}\right)$} \\
\hline $\mathrm{H}_{2}, \mathrm{~mol} /\left(\mathrm{mol}-\mathrm{CH}_{4}\right.$ in Feed $)$ & 2.58 & 2.36 & 2.28 & 2.35 \\
\hline $\mathrm{CO}_{2}, \mathrm{~mol} /\left(\mathrm{mol}-\mathrm{CH}_{4}\right.$ in Feed $)$ & 1.33 & 0.885 & 0.637 & 0.587 \\
\hline $\mathrm{CO}, \mathrm{mol} /\left(\mathrm{mol}-\mathrm{CH}_{4}\right.$ in Feed $)$ & 0.837 & 0.788 & 0.700 & 0.706 \\
\hline $\mathrm{CH}_{4}, \mathrm{~mol} /\left(\mathrm{mol}-\mathrm{CH}_{4}\right.$ in Feed $)$ & 0.065 & 0.125 & 0.162 & 0.192 \\
\hline $\mathrm{H}_{2}, \mathrm{~mol} /\left(\mathrm{mol}-\mathrm{CH}_{4}+\mathrm{H}_{2} \mathrm{O}\right.$ in Feed $)$, Eqn. 9 & 0.61 & 0.67 & 0.73 & 0.79 \\
\hline $\mathrm{CO}, \mathrm{mol} /\left(\mathrm{mol}-\mathrm{CH}_{4}+\mathrm{CO}_{2}\right.$ in Feed $)$, Eqn. 10 & 0.33 & 0.40 & 0.42 & 0.46 \\
\hline Carbon Balance $\left(650^{\circ} \mathrm{C}\right)$ & 0.909 & 0.886 & 0.906 & 0.959 \\
\hline \multicolumn{5}{|l|}{ Equilibrium Product Yields $\left(650^{\circ} \mathrm{C}\right)$} \\
\hline $\mathrm{H}_{2}, \mathrm{~mol} /\left(\mathrm{mol}-\mathrm{CH}_{4}\right.$ in Feed $)$ & 2.82 & 2.72 & 2.62 & 2.57 \\
\hline $\mathrm{CO}_{2}, \mathrm{~mol} /\left(\mathrm{mol}-\mathrm{CH}_{4}\right.$ in Feed $)$ & 1.51 & 1.01 & 0.718 & 0.626 \\
\hline $\mathrm{CO}, \mathrm{mol} /\left(\mathrm{mol}-\mathrm{CH}_{4}\right.$ in Feed $)$ & 0.940 & 0.863 & 0.787 & 0.754 \\
\hline $\mathrm{CH}_{4}, \mathrm{~mol} /\left(\mathrm{mol}-\mathrm{CH}_{4}\right.$ in Feed $)$ & 0.061 & 0.104 & 0.149 & 0.169 \\
\hline $\mathrm{O} / \mathrm{C}$ in Feed, atomic ratio & \multicolumn{4}{|c|}{2.26} \\
\hline $\mathrm{S} / \mathrm{C}, \mathrm{H}_{2} \mathrm{O} /\left(\mathrm{CO}+\mathrm{CH}_{4}\right)$ in Feed, molar ratio & 1.06 & 1.28 & 1.47 & 1.55 \\
\hline $\mathrm{H}_{2} \mathrm{O} / \mathrm{CH}_{4}$ in Feed, $\mathrm{S} / \mathrm{M}$, molar ratio & 2.65 & 2.52 & 2.43 & 2.40 \\
\hline $\mathrm{O} / \mathrm{CH}_{4}$ in Feed, atomic ratio & 6.23 & 4.48 & 3.42 & 3.07 \\
\hline GHSV, $\mathrm{hr}^{-1}$ & 10,760 & 9,930 & 9,400 & 9,220 \\
\hline $\mathrm{CH}_{4}$ Conversion, $\%$ & 91.3 & 89.1 & 87.4 & 86.4 \\
\hline Equilibrium Conversion $\left(650^{\circ} \mathrm{C}\right)$ & 91.97 & 89.6 & 87.8 & 87.1 \\
\hline \multicolumn{5}{|l|}{ Experimental Product Yields $\left(650^{\circ} \mathrm{C}\right)$} \\
\hline $\mathrm{H}_{2}, \mathrm{~mol} /\left(\mathrm{mol}-\mathrm{CH}_{4}\right.$ in Feed $)$ & 2.54 & 2.56 & 2.54 & 2.53 \\
\hline $\mathrm{CO}_{2}, \mathrm{~mol} /\left(\mathrm{mol}-\mathrm{CH}_{4}\right.$ in Feed $)$ & 1.31 & 0.962 & 0.741 & 0.672 \\
\hline $\mathrm{CO}, \mathrm{mol} /\left(\mathrm{mol}-\mathrm{CH}_{4}\right.$ in Feed $)$ & 0.944 & 0.789 & 0.671 & 0.634 \\
\hline $\mathrm{CH}_{4}, \mathrm{~mol} /\left(\mathrm{mol}-\mathrm{CH}_{4}\right.$ in Feed $)$ & 0.087 & 0.109 & 0.126 & 0.136 \\
\hline $\mathrm{H}_{2}, \mathrm{~mol} /\left(\mathrm{mol}-\mathrm{CH}_{4}+\mathrm{H}_{2} \mathrm{O}\right.$ in Feed $)$, Eqn. 9 & 0.70 & 0.73 & 0.74 & 0.74 \\
\hline $\mathrm{CO}, \mathrm{mol} /\left(\mathrm{mol}-\mathrm{CH}_{4}+\mathrm{CO}_{2}\right.$ in Feed $)$, Eqn. 10 & 0.38 & 0.40 & 0.41 & 0.41 \\
\hline Carbon Balance $\left(650^{\circ} \mathrm{C}\right)$ & 0.932 & 0.941 & 0.929 & 0.932 \\
\hline \multicolumn{5}{|l|}{ Equilibrium Product Yields $\left(650^{\circ} \mathrm{C}\right)$} \\
\hline $\mathrm{H}_{2}, \mathrm{~mol} /\left(\mathrm{mol}-\mathrm{CH}_{4}\right.$ in Feed $)$ & 2.66 & 2.72 & 2.76 & 2.77 \\
\hline $\mathrm{CO}_{2}, \mathrm{~mol} /\left(\mathrm{mol}-\mathrm{CH}_{4}\right.$ in Feed $)$ & 1.41 & 1.01 & 0.779 & 0.707 \\
\hline
\end{tabular}




\begin{tabular}{|l|c|c|c|c|}
\hline $\mathrm{CO}, \mathrm{mol} /\left(\mathrm{mol}-\mathrm{CH}_{4}\right.$ in Feed $)$ & 1.02 & 0.863 & 0.752 & 0.713 \\
\hline $\mathrm{CH}_{4}, \mathrm{~mol} /\left(\mathrm{mol}_{-}-\mathrm{CH}_{4}\right.$ in Feed $)$ & 0.0803 & 0.104 & 0.149 & 0.169 \\
\hline
\end{tabular}

\subsection{Catalyst Durability}

Comparing the gas yields from the reforming experiments over the course of the experimental plan presents a glimpse into the durability of the catalyst. Table 7 shows the product gas yields for experiments that were reasonably close in the operating conditions, which were approximately at $650^{\circ} \mathrm{C}, \mathrm{S} / \mathrm{C}=1.28-1.31$, and $\mathrm{GHSV}=9,810-9,930$ $\mathrm{hr}^{-1}$ with a feed gas containing a $\mathrm{CO}_{2} / \mathrm{CH}_{4}=0.98$. The table also shows the accumulated experimental time on stream. The conversion data are plotted in Figure 13, and shows only a very small drop in conversion after 34 hours on stream, even though the measured BET surface area decreased by $\sim 16 \%$ during that period.

\section{Table 7. Effect of time on stream on conversions and product gas yields}

\begin{tabular}{|c|c|c|c|c|c|c|c|c|c|}
\hline & Initial & & & & & & & & Final \\
\hline Time on Stream, hr & & 5.7 & 15.0 & 24.3 & 26.8 & 28.2 & 32.0 & 34.0 & \\
\hline $\mathrm{CO}_{2} / \mathrm{CH}_{4}$ & & 0.98 & 0.98 & 0.98 & 0.98 & 0.98 & 0.98 & 0.98 & \\
\hline $\mathrm{H}_{2} \mathrm{O} / \mathrm{CH}_{4}$ & & 1.32 & 1.32 & 1.32 & 1.28 & 1.28 & 1.28 & 1.28 & \\
\hline Temperature, ${ }^{\circ} \mathrm{C}$ & & 650 & 650 & 650 & 650 & 650 & 650 & 650 & \\
\hline Gas Hourly Space Velocity, $\mathrm{hr}^{-1}$ & & 9,810 & 9,810 & 9,810 & 9,930 & 9,930 & 9,930 & 9,930 & \\
\hline \multicolumn{10}{|l|}{ Product Yield, } \\
\hline $\mathrm{H}_{2}, \mathrm{~mol} /\left(\mathrm{mol}-\mathrm{CH}_{4}\right.$ in Feed $)$ & & 2.58 & 2.62 & 2.49 & 2.36 & 2.58 & 2.28 & 2.56 & \\
\hline $\mathrm{CO}_{2}, \mathrm{~mol} /\left(\mathrm{mol}-\mathrm{CH}_{4}\right.$ in Feed $)$ & & 0.93 & 0.98 & 0.93 & 0.88 & 1.33 & 0.64 & 0.96 & \\
\hline $\mathrm{CH}_{4}, \mathrm{~mol} /\left(\mathrm{mol}-\mathrm{CH}_{4}\right.$ in Feed $)$ & & 0.11 & 0.12 & 0.13 & 0.12 & 0.07 & 0.16 & 0.11 & \\
\hline $\mathrm{CO}, \mathrm{mol} /\left(\mathrm{mol}-\mathrm{CH}_{4}\right.$ in Feed $)$ & & 0.88 & 0.85 & 0.82 & 0.79 & 0.84 & 0.70 & 0.79 & \\
\hline $\mathrm{CH} 4$ Conversion, $\%$ & & 89.3 & 88.5 & 87.2 & 87.5 & 93.5 & 83.8 & 89.1 & \\
\hline BET Surface Area, $\mathrm{m}^{2} / \mathrm{g}$ & 122 & & & & & & & & 102 \\
\hline
\end{tabular}




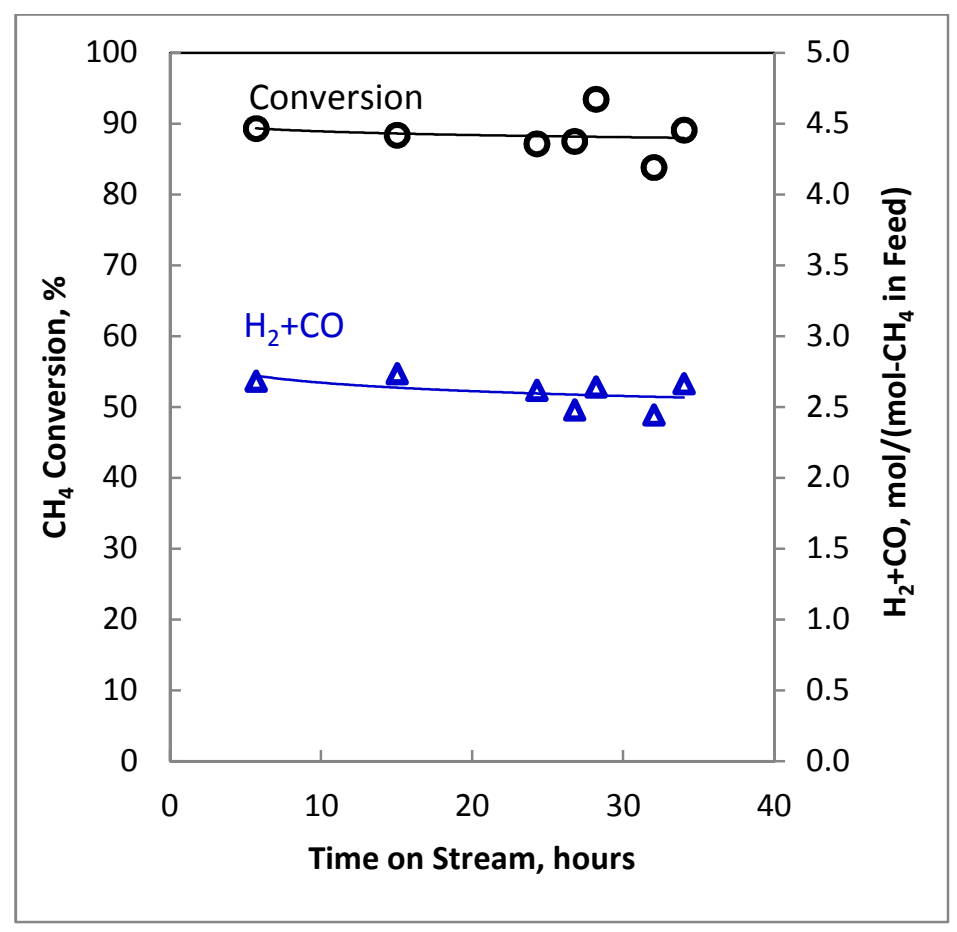

Figure 13. $\mathrm{CH}_{4}$ Conversion vs. Time on Stream

\section{Summary and Conclusions}

The experimental study on the steam reforming of biogas mixtures on a rhodium catalyst has shown that the methane conversion increases with temperature, the $\mathrm{S} / \mathrm{C}$ molar ratio, the $\mathrm{CO}_{2} / \mathrm{CH}_{4}$ molar ratio, and the residence time. The highest methane conversion observed was $99 \%$ when the reaction was conducted with feed with $\mathrm{CO}_{2} / \mathrm{CH}_{4}=0.98, \mathrm{~S} / \mathrm{C}=3.87, \mathrm{~S} / \mathrm{M}=7.64, \mathrm{O} / \mathrm{C}=4.85, \mathrm{GHSV}=19,600 \mathrm{hr}^{-1}$, and the product gases exited the catalyst bed at $650^{\circ} \mathrm{C}$. This was the only condition where the experimental conversion approached the equilibrium predicted conversion. The effect of steam has a very pronounced effect on the methane conversion. Except for this set of operating conditions, experimental conversions fell short of equilibrium predicted values, even at the combination of the lowest GHSV of $9,810 \mathrm{hr}^{-1}$ and the highest exit temperature of $671^{\circ} \mathrm{C}$. The combination of temperature and GHSV changes indicate that the water gas shift reaction has a stronger effect on the $\mathrm{CO}_{2}$ conversion and yield than the $\mathrm{CO}_{2}$ reforming reaction. A study of the effect of the $\mathrm{CO}_{2} / \mathrm{CH}_{4}$ ratio showed that the presence of $\mathrm{CO}_{2}$ in biogas adds to the $\mathrm{CO}$ yield (beyond that produced from only the steam reforming reaction) above certain $\mathrm{O} / \mathrm{C}$ and $\mathrm{S} / \mathrm{C}$ ratios. At $650^{\circ} \mathrm{C}$, this occurred at $\mathrm{CO}_{2} / \mathrm{CH}_{4}=1.4$ when the the $\mathrm{O} / \mathrm{C}=2.26$. 


\section{Acknowledgments}

The authors wish to acknowledge Dionissios D. Papadias for his help in preparing this manuscript. This work was supported by the U.S. Department of Energy's Bioenergy Technologies Office. Argonne National Laboratory is managed for the U.S. Department of Energy by UChicago Argonne, LLC, under contract DE-AC-02-06CH11357.

\section{References}

1. Samson R, LeDuy A. Biogas production from anaerobic digestion of spirulina maxima algal biomass. Biotechnology and Bioengineering 2012; 24(8):1919-24

2. Rasi S, Veijanen A, Rintala J. Trace compounds of biogas from different biogas production plants. Energy 2007; 32:1370-80

3. Weiland P. Biogas production: current state and perspectives. Applied Microbiology Biotechnology 2010; 85:849-60

4. Andriani D, Wresta A, Atmaja T. A review on optimization production and upgrading biogas through $\mathrm{CO} 2$ removal using various techniques. Applied Biochem Biotechnol 
$2014 ; 172: 1909-28$

5. Ozturk B, Demirciyeva F. Compariosn of biogas upgrading performances of different mixed matrix membranes. Chemical Engineering Journal 2013; 222:209-17

6. Makaruk A, Miltner M, Harasek M. Membrane biogas upgrading processes for the production of natural gas substitute. Separation ad Purification Technology 2010; 74:83-

92

7. Izquierdo U, Barrio V, Lago N, Requies JCambra J, Guemez M, Arias P. Biogas steam and oxidative reforming processes for synthesis gas and hydrogen production in conventional microreactor reaction systems. International Journal of Hydrogen Energy 2012; 37:13829-42

8. Lau C, Tsolakis A, Wyszynski M. Biogas upgrade to syn-gas $(\mathrm{H} 2-\mathrm{CO})$ via dry and oxidative reforming. International Journal of Hydrogen Energy 2011; 36(1):397-404

9. Kolbitsch P, Pfeifer P, Hofbauer H. Catalytic steam reforming of model biogas. Fuel 2008; 87:701-06

10. Avraam D, Halkides T, Liguras D, Bereketidou O, Goula M. An experimental and theoretical approach for the biogas steam reforming reaction. International Journal of Hydrogen Energy 2010; 35:9818-27

11. Alyes $E$, He D, Wang J. Alcohol synthesis from syngas: I. Performance of alkali-promoted Ni-Mo (MOVS) catalysts. Journal of Applied Catalysis 1993; 104:77-85

12. Burch R, Petch M. Investigation of the synthesis of oxygenates from carbon monoxide / hydrogen mixtures on supported rhodium catalysts. Applied Catalysis 1992; 88:39-60

13. Wang S, Lu G, Millar G. Carbon dioxide reforming of methane to produce synthesis gas over metal supported catalysts: state of the art. Energy and Fuels 1996; 10:896-904

14. Vannice M. The catalytic synthesis of hydrocarbons from carbon monoxide and hydrogen. Catalysis Review - Science and Engineering 1976; 14(2):153-91

15. Chen $\mathrm{Y}$, Tomishige K, Fujimoto K. Formation and characteristic properties of carbonaceous species on nickel-magnesia solid solution catalysts during $\mathrm{CH} 4-\mathrm{CO} 2$ reforming reaction. Applied Catalysis A 1997; 161:L11-17

16. Ito $M$, Tagawa $T$, Goto S. Suppression of carbonaceous depositions on nickel catalyst for carbon dioxide reforming of methane. Applied Catalysis A 1999; 177(10):15-23 
17. Ruckenstein $\mathrm{E}$, Wang $\mathrm{H}$. Carbon deposition and catalytic deactivation during $\mathrm{CO} 2$ reforming of $\mathrm{CH} 4$ over Co/Al2O3 catalyst. Journal of Catalysis 2002; 205:289-293.

18. Li C, Fu Y, Bian G, Xie Y, Hu T, Zhang J. Effect of steam in $\mathrm{CO} 2$ reforming of $\mathrm{CH} 4$ over a $\mathrm{Ni} / \mathrm{CeO} 2-\mathrm{ZrO} 2-\mathrm{Al} 2 \mathrm{O} 3$ catalyst. Kinetics and Catalysis 2004; 45(5):679-83

19. Effendi Z, Zhang Z-G, Hellgardt K, Honda K, Yoshida T. Steam reforming of a clean model biogas over Ni/Al2O3 in fluidized- and fixed-bed reactors. Catalysis Today 2002; 77:18189

20. Effendi A, Hellgardt K, Zhang Z-G, Yoshida T. "Optimizing H2 production from model biogas via combined steam reforming and CO shift reactions," Fuel 2005; 84:869-74

21. Araki S, Hino N, More T, Hikazudani S. Durability of a Ni monolithic catalyst in the autothermal reforming of biogas. International Journal of Hydrogen Energy 2009; 34:4727-34

22. Xu J, Zhou W, Li Z, Wang J, Ma J. Biogas reforming for hydrogen production over a Ni-Co bimetallic catalyst: Effect of operating conditions. International Journal of Hydrogen Energy 2010; 35:13013-20

23. Araki S, Hino N, More T, Hikazudani S. Autothermal reforming of biogas over a monolithic catalyst. Journal of Natural Gas Chemistry 2010; 19:477-81

24. Ferrandon M, Krause T. Role of the oxide support on the performance of Rh catalysts for the autothermal reforming of gasoline and gasoline surrogates to hydrogen. Applied Catalysis A 2006; 311:135-45

25. Adachi H, Ahmed S, Lee S, Papadias D, Ahluwalia R. A natural gas fuel processor for a residential fuel cell system. Journal of Power Sources 2009; 188:244-55

26. Papadias D, Lee S, Ferrandon M, Ahmed S. An analytical and experimental investigation of high pressure catalytic steam reforming of ethanol. International Journal of Hydrogen Energy 2010; 35:2004-17

27. HSC Chemistry 5.1, 2002.

28. Lin $\mathrm{K}-\mathrm{H}$, Chang $\mathrm{H}-\mathrm{F}$, Chang $\mathrm{C}-\mathrm{C}$. Biogas reforming for hydrogen production over mesoporous Ni2xCe21-xO2 catalysts. International Journal of Hydrogen Energy 2012; 37:15696-703

29. Chiodo V, Urbani F, Galvagno A, Mondello N, Freni S. Analysis of biogas reforming process for molten carbonate fuel cells. Journal of Power Sources 2012; 206:215-21 
30. Bauer F, Persson T, Hulteberg C, Tamm D. Biogas upgrading - technology overview, comparison, and perspectives for the future. Biofuels Bioproducts and Biorefining-Biofpr 2013; 7(5):499-511

31. Stern S, Krishnakumar B, Charati S, Amato W, Friedman A, Fuess D. Performance of a bench scale membrane pilot plant for the upgrading of biogas in a wastewater treatment plant, Journal of Membrane Science 1998; 151:63-74

32. Rautenbach $\mathrm{R}$, Welsch $\mathrm{K}$. Treatment of landfill gas by gas permeation. Pilot plant results and comparison to alternatives. Journal of Membrane Science 1994; 87:107-18 